\title{
Scaffold morphing identifies 3-pyridyl azetidine ureas as inhibitors of nicotinamide phosphoribosyltransferase (NAMPT)
}

Daniel S. Palacios, ${ }^{*} \dagger$ Erik L. Meredith, ${ }^{\dagger}$ Toshio Kawanami, ${ }^{\dagger}$ Christopher M. Adams,${ }^{\dagger}$ Xin Chen, ${ }^{\dagger}$ Veronique Darsigny, ${ }^{\dagger}$ Mark Palermo, ${ }^{\dagger}$ Daniel Baird, ${ }^{\ddagger}$ Elizabeth L. George,${ }^{\ddagger}$ Chantale Guy, $\ddagger$ Jeffrey Hewett, $¥$ Laryssa Tierney, ${ }^{\ddagger}$ Sachin Thigale, ${ }^{\ddagger}$ Louis Wang, ${ }^{\ddagger}$ Wilhelm A. Weihofen $¥$

† Global Discovery Chemistry, Novartis Institute for Biomedical Research, 22 Windsor St, Cambridge MA, 02139 $\ddagger$ Chemical Biology and Therapeutics, Novartis Institute for Biomedical Research, 181 Massachusetts Ave, Cambridge MA, 02139

\section{Supporting information}

Synthetic procedures for representative compounds and associated analytical data as well as analytical data for additional compounds and intermediates. In addition, the methods for the cellular assay and xenograft study are also included.

General. NMR spectra were obtained using a Bruker Avance II $400 \mathrm{MHz}$ NMR spectrometer. All chemical shifts are reported in parts per million $(\delta)$ relative to tetramethylsilane. The following abbreviations are used to denote splitting patterns: $s=s i n g l e t, d=$ doublet, $t=$ triplet, $d d=d$ doublet of doublets, $m=$ multiplet. Low resolution MS were obtained using an Agilent 1100 series LCMS spectrometer. High resolution MS were obtained using a Water AcQuity UPLC connected to a Waters Xevo G2 Qtof mass spectrometer. Compounds were purified using Teledyne Isco Combiflash automated purification systems. The cell based and biochemical data are the average of three replicates.

\section{Abbreviations}

$\begin{array}{ll}\text { app } & \begin{array}{l}\text { apparent } \\ \text { aq }\end{array} \\ \text { atm } & \begin{array}{l}\text { atmosphere } \\ \text { BINAP }\end{array} \\ \text { Bn } & \text { benzyl -bis(diphenylphosphino)-1,1'-binaphthalene } \\ \text { BOC } & \text { tert-butyl carboxy } \\ \text { br } & \text { broad } \\ \text { BSA } & \text { bovine serum albumin } \\ \text { Cbz } & \text { carbobenzyloxy } \\ \text { d } & \text { doublet } \\ \text { D } & \text { deuterium } \\ \text { DCE } & 1,2-\text { dichloroethane } \\ \text { dd } & \text { doublet of doublets }\end{array}$




\begin{tabular}{|c|c|}
\hline DCM & dichloromethane \\
\hline DEA & diethylamine \\
\hline DIEA, DIPEA & diisopropylethylamine \\
\hline DMA & $\mathrm{N}, \mathrm{N}$-dimethylacetamide \\
\hline DMAP & 4,4-dimethylaminopyridine \\
\hline DME & 1,2-dimethoxyethane \\
\hline DMF & $\mathrm{N}, \mathrm{N}$-dimethylformamide \\
\hline DMSO & dimethylsulfoxide \\
\hline DTT & dithiothreitol \\
\hline ee & enantiomeric excess \\
\hline ESI & electrospray ionization \\
\hline EtOAc & ethyl acetate \\
\hline FCC & flash column chromatography \\
\hline g & grams \\
\hline h & hour(s) \\
\hline HATU & $\begin{array}{l}\text { 2-(3H-[1,2,3]triazolo[4,5-b]pyridin-3-yl)-1,1,3,3-tetramethylisouronium } \\
\text { hexafluorophosphate }(\mathrm{V})\end{array}$ \\
\hline HPLC & high pressure liquid chromatography \\
\hline IR & infrared spectroscopy \\
\hline LAH & lithium aluminum hydride \\
\hline LCMS & liquid chromatography and mass spectrometry \\
\hline M & molar \\
\hline $\mathrm{m}$ & multiplet \\
\hline $\mathrm{MeCN}, \mathrm{CH}_{3} \mathrm{CN}$ & acetonitrile \\
\hline $\mathrm{MeOH}$ & methanol \\
\hline $\min$ & minutes \\
\hline $\mathrm{mL}$ & milliliter(s) \\
\hline $\mathrm{mmol}$ & millimoles \\
\hline MS & mass spectrometry \\
\hline MW & microwave \\
\hline $\mathrm{m} / \mathrm{z}$ & mass to charge ratio \\
\hline$N$ & normal \\
\hline NMR & nuclear magnetic resonance \\
\hline PBS & phosphate buffer solution \\
\hline
\end{tabular}




$\begin{array}{ll}\mathrm{Pd} / \mathrm{C} & \text { palladium on carbon } \\ \mathrm{ppm} & \text { parts per million } \\ \mathrm{rac} & \text { racemic } \\ \mathrm{rt} & \text { room temperature } \\ \mathrm{rT} & \text { retention time } \\ \mathrm{s} & \text { singlet } \\ \text { sat } & \text { saturated } \\ \mathrm{SFC} & \text { Supercritical Fluid Chromatography } \\ \mathrm{t} & \text { triplet } \\ \text { TBSCl } & \text { tert-butyldimethylsilyl chloride } \\ \text { Tf } & \text { Trifluoromethanesulfonate } \\ \text { TFA } & \text { trifluoroacetic acid } \\ \text { THF } & \text { tetrahydrofuran }\end{array}$

\section{Preparations of compounds}

Compound 1: 1-((6-aminopyridin-3-yl)methyl)-3-(4-((1,3-dioxoisoindolin-2yl)methyl)phenyl)urea<smiles>Nc1ccc(CNC(=O)Nc2ccc(CN3C(=O)c4ccccc4C3=O)cc2)cn1</smiles>

See Palacios D.S. et al Bioorg Med Chem Lett 2018, 28, 365-370 for the synthesis of this compound.

Compound 2: (1S,2S)-N-(4-((1,3-dioxoisoindolin-2-yl)methyl)phenyl)-2-(pyridin-3yl)cyclopropane-1-carboxamide<smiles>O=C(Nc1ccc(CN2C(=O)c3ccccc3C2=O)cc1)C1C[C@H]1c1cccnc1</smiles>

See Palacios D.S. et al Bioorg Med Chem Lett 2018, 28, 365-370 for the synthesis of this compound. 

carboxamide<smiles>O=C(Nc1ccc(CN2C(=O)c3ccccc3C2=O)cc1)N1CC(c2cccnc2)C1</smiles>

2-(4-aminobenzyl)isoindoline-1,3-dione (commercially available, $67 \mathrm{mg}, 0.265 \mathrm{mmol}$ ) was dissolved in THF $(3 \mathrm{~mL})$ and cooled to $0{ }^{\circ} \mathrm{C}$. trichloromethyl carbonochloridate $(63 \mathrm{mg}, 0.317$ mmol) and DIPEA (164 mg, $1.27 \mathrm{mmol}$ ) were added and the reaction was stirred for 15 minutes. Next, 3-(azetidin-3-yl)pyridine (71 mg, $0.529 \mathrm{mmol}$, see below for preparation) in THF (2 mL) was added followed by additional DIPEA $(0.08 \mathrm{~mL})$. The reaction was stirred for 16 hours. The reaction was then diluted with EtOAc $(50 \mathrm{~mL})$ and washed with water $(2 \times 50 \mathrm{~mL})$ and brine $(1 \times 50 \mathrm{~mL})$ and concentrated. The material was then purified by preparative reverse phase HPLC (SunFire 30x50 $\mathrm{mm} 5 \mu \mathrm{M} \mathrm{10-30 \%} \mathrm{MeCN/H2O} \mathrm{(0.1 \%} \mathrm{TFA),} 75 \mathrm{~mL} / \mathrm{min})$. The isolated solid was then diluted with $\mathrm{MeOH}(3 \mathrm{~mL})$ and absorbed onto a $10 \mathrm{~g} \mathrm{SCX}$ column. The column was washed with $\mathrm{MeOH}$ and then the product was eluted with $7 \mathrm{~N}$ ammonia in $\mathrm{MeOH}$ to yield the title compound as a white powder (46 mg, $0.096 \mathrm{mmol})$.

MS calculated for $\mathrm{C}_{24} \mathrm{H}_{21} \mathrm{~N}_{4} \mathrm{O}_{3}[\mathrm{M}+\mathrm{H}]^{+}:$: 413.2; found $413.2(\mathrm{ESI}+)$

1H NMR (400 MHz, DMSO-d6) ס 8.61 - 8.51 (m, 2H), 8.47 (dd, J = 4.8, 1.6 Hz, 1H), $7.95-7.81$ $(\mathrm{m}, 5 \mathrm{H}), 7.53-7.34(\mathrm{~m}, 3 \mathrm{H}), 7.22-7.12(\mathrm{~m}, 2 \mathrm{H}), 4.69(\mathrm{~s}, 2 \mathrm{H}), 4.36(\mathrm{t}, \mathrm{J}=8.3 \mathrm{~Hz}, 2 \mathrm{H}), 3.94$ (dd, $\mathrm{J}=8.1,6.0 \mathrm{~Hz}, 2 \mathrm{H}), 3.89-3.80(\mathrm{~m}, 1 \mathrm{H})$.

Compound 4: N-(4-((1-oxoisoindolin-2-yl)methyl)phenyl)-3-(pyridin-3-yl)azetidine-1carboxamide<smiles>O=C(Nc1ccc(CN2Cc3ccccc3C2=O)cc1)N1CC(c2cccnc2)C1</smiles>

Step 1: 2-(4-nitrobenzyl)isoindolin-1-one 
To a solution of isoindolin-1-one (400 mg, $3.00 \mathrm{mmol})$ and 1-(bromomethyl)-4-nitrobenzene (1298 $\mathrm{mg}, 6.01 \mathrm{mmol}$ ) in MeCN (7.5 mL) was added Cs2CO3 (3915 mg, $12.02 \mathrm{mmol})$. The reaction was stirred for $16 \mathrm{hr}$ at RT. The reaction was filtered on over celite, concentrated and taken up in DCM $(100 \mathrm{~mL})$. The DCM was washed with a solution of $3 \mathrm{~N} \mathrm{HCl}(25 \mathrm{~mL})$. The aqueous phase was extracted twice with DCM $(2 \times 25 \mathrm{~mL})$. The organics were combined, washed with brine $(1 \times 10 \mathrm{~mL})$, dried with sodium sulfate, filtered and concentrated. The crude was purified by FCC $(0-40 \%$ EtOAc/heptanes) to afford the title compound (613 $\mathrm{mg}, 2.057 \mathrm{mmol})$.

MS calculated for $\mathrm{C}_{15} \mathrm{H}_{13} \mathrm{~N}_{2} \mathrm{O}_{3}[\mathrm{M}+\mathrm{H}]^{+}:$269.1; found 269.2 (ESI+).

Step 2: 2-(4-aminobenzyl)isoindolin-1-one

2-(4-nitrobenzyl)isoindolin-1-one (613 mg, $2.285 \mathrm{mmol})$ was dissolved in $\mathrm{EtOH}$ (22 $\mathrm{mL}$ ) and Water $(8.8 \mathrm{~mL})$ and zinc $(747 \mathrm{mg}, 11.43 \mathrm{mmol})$ and $\mathrm{NH} 4 \mathrm{Cl}(611 \mathrm{mg}, 11.43 \mathrm{mmol})$ were added. The reaction was stirred at $50^{\circ} \mathrm{C}$ for 1 hour. The reaction was cooled to $\mathrm{RT}$, filtered and concentrated. It was then dissolved in EtOAc $(200 \mathrm{~mL})$ and washed with sat. aq. NaHCO3 (2x50 mL). The aqueous phase was extracted with EtOAc $(3 \times 25 \mathrm{~mL})$ and the combined organics were washed with brine $(1 \times 10 \mathrm{~mL})$, dried with sodium sulfate, filtered and concentrated to obtain the title compound (482 $\mathrm{mg}, 1.841 \mathrm{mmol})$ as a yellow solid which was used without further purification. MS calculated for $\mathrm{C}_{15} \mathrm{H}_{15} \mathrm{~N}_{2} \mathrm{O}[\mathrm{M}+\mathrm{H}]^{+}:$:239.1; found 239.0 (ESI+).

Step 2: N-(4-((1-oxoisoindolin-2-yl)methyl)phenyl)-3-(pyridin-3-yl)azetidine-1-carboxamide 2-(4-aminobenzyl)isoindolin-1-one $(36 \mathrm{mg}, 0.149 \mathrm{mmol})$ was dissolved in THF $(2 \mathrm{~mL})$ and trichloromethyl carbonochloridate $(36 \mathrm{mg}, 0.179 \mathrm{mmol}$ ) and DIPEA (92 $\mathrm{mg}, 0.715 \mathrm{mmol}$ ) were added. The reaction was cooled to $0{ }^{\circ} \mathrm{C}$ and stirred for 15 minutes and then 3-(azetidin-3yl)pyridine (40 mg, $0.298 \mathrm{mmol}$, see below for synthesis) dissolved in THF (2 mL) and DIPEA $(0.13 \mathrm{~mL})$ were added and the reaction was warmed to RT and stirred for 16 hours. The reaction was diluted with EtOAc $(50 \mathrm{~mL})$ and washed with water $(2 \times 50 \mathrm{~mL})$ and brine $(1 \times 50 \mathrm{~mL})$ and concentrated. The material was then purified by preparative reverse phase HPLC (SunFire 30x50 $\mathrm{mm} 5 \mu \mathrm{M} \mathrm{10-30 \%} \mathrm{MeCN/H2O} \mathrm{(0.1 \%} \mathrm{TFA),} 75 \mathrm{~mL} / \mathrm{min})$. The isolated solid was then diluted with $\mathrm{MeOH}(3 \mathrm{~mL})$ and absorbed onto a $10 \mathrm{~g} \mathrm{SCX}$ column. The column was washed with $\mathrm{MeOH}$ and then the product was eluted with $7 \mathrm{~N}$ ammonia in $\mathrm{MeOH}$ to yield the title compound as a white powder (19 mg, $0.044 \mathrm{mmol})$.

MS calculated for $\mathrm{C}_{24} \mathrm{H}_{23} \mathrm{~N}_{4} \mathrm{O}_{3}[\mathrm{M}+\mathrm{H}]^{+}: 399.2$; found 399.2 (ESI+)

${ }^{1} \mathrm{H}$ NMR $\left(400 \mathrm{MHz}\right.$, DMSO- $\left.\mathrm{d}_{6}\right) \delta 8.62-8.53(\mathrm{~m}, 2 \mathrm{H}), 8.48(\mathrm{dd}, \mathrm{J}=4.8,1.6 \mathrm{~Hz}, 1 \mathrm{H}), 7.87(\mathrm{dt}, \mathrm{J}=$ 8.0, $2.0 \mathrm{~Hz}, 1 \mathrm{H}), 7.72(\mathrm{~d}, \mathrm{~J}=7.5 \mathrm{~Hz}, 1 \mathrm{H}), 7.63-7.54(\mathrm{~m}, 2 \mathrm{H}), 7.54$ - $7.46(\mathrm{~m}, 3 \mathrm{H}), 7.44$ - $7.35(\mathrm{~m}$, $1 \mathrm{H}), 7.21$ - $7.12(\mathrm{~m}, 2 \mathrm{H}), 4.65(\mathrm{~s}, 2 \mathrm{H}), 4.45$ - $4.31(\mathrm{~m}, 4 \mathrm{H}), 3.95(\mathrm{dd}, \mathrm{J}=8.1,6.0 \mathrm{~Hz}, 2 \mathrm{H}), 3.90$ $3.78(\mathrm{~m}, 1 \mathrm{H})$. 


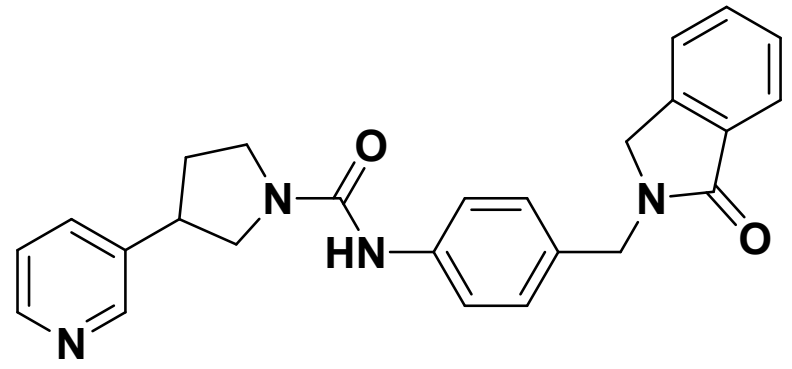

Step 1: tert-butyl 3-(pyridin-3-yl)-2,5-dihydro-1H-pyrrole-1-carboxylate

To a solution of 3-bromopyridine $(70.1 \mu \mathrm{L}, 0.728 \mathrm{mmol})$, tert-butyl 3-(4,4,5,5-tetramethyl-1,3,2dioxaborolan-2-yl)-2,5-dihydro-1 $\mathrm{H}$-pyrrole-1-carboxylate $\left(258 \mathrm{mg}, 0.873 \mathrm{mmol}\right.$ ) and $2 \mathrm{M} \mathrm{K}_{3} \mathrm{PO}_{4}$ $(1820 \mu \mathrm{L}, 3.64 \mathrm{mmol})$ in $\mathrm{MeCN}(7.3 \mathrm{~mL})$ was added $\mathrm{PdCl}_{2}(\mathrm{dppf})(21.30 \mathrm{mg}, 0.029 \mathrm{mmol}) . \mathrm{N}_{2}$ was bubbled through the solution for $10 \mathrm{~min}$ and the resulting mixture was stirred at $110{ }^{\circ} \mathrm{C}$ for 45 minutes in the microwave. The reaction was then diluted in EtOAc $(100 \mathrm{~mL})$ and water $(25 \mathrm{~mL})$. The phases were separated and the aqueous phase was extracted with EtOAc $(3 \times 25 \mathrm{~mL})$. The combined organics were washed with brine $(1 \times 10 \mathrm{~mL})$, dried with sodium sulfate, filtered and concentrated under reduced pressure. The crude was purified by FCC (20-70\% EtOAc/heptanes) to give the title compound ( $86 \mathrm{mg}, 0.349 \mathrm{mmol}$ ).

MS calculated for $\mathrm{C}_{14} \mathrm{H}_{19} \mathrm{~N}_{2} \mathrm{O}_{2}[\mathrm{M}+\mathrm{H}]^{+}:$247.1; found 247.1 (ESI+).

Step 2: 3-(2,5-dihydro-1H-pyrrol-3-yl)pyridine

To a solution of tert-butyl 3-(pyridin-3-yl)-2,5-dihydro-1H-pyrrole-1-carboxylate (86 mg, 0.349 $\mathrm{mmol})$ in $\mathrm{DCM}(0.5 \mathrm{~mL})$ was added $\mathrm{HCl} 4 \mathrm{~N}$ in dioxane $(1.8 \mathrm{~mL})$. After stirring for 1 hour the reaction was concentrated and used directly in the next step.

Step 3: N-(4-((1-oxoisoindolin-2-yl)methyl)phenyl)-3-(pyridin-3-yl)-2,5-dihydro-1H-pyrrole-1carboxamide

To a solution of 2-(4-aminobenzyl)isoindolin-1-one $(60 \mathrm{mg}, 0.252 \mathrm{mmol})$ and DIPEA (176 $\mu \mathrm{L}$, $1.007 \mathrm{mmol})$ in DCE $(1.3 \mathrm{~mL})$ was added phenyl chloroformate $(44.4 \mu \mathrm{l}, 0.353 \mathrm{mmol})$ at $0{ }^{\circ} \mathrm{C}$ and the reaction was stirred for 20 minutes. 3-(2,5-dihydro-1H-pyrrol-3-yl)pyridine (66.2 mg, 0.302 $\mathrm{mmol}$ ) was then added to the mixture and the resulting solution was stirred at $40{ }^{\circ} \mathrm{C}$ for 16 hours. It was then cooled to RT and sat aq. sodium bicarbonate $(10 \mathrm{~mL})$ was added and the solution was extracted with EtOAc $(3 \times 25 \mathrm{~mL})$. The combined organics were washed with brine $(2 \times 10 \mathrm{~mL})$, dried with sodium sulfate, filtered and concentrated. The crude was purified by FCC $(0-10 \%$ $\left.\mathrm{MeOH}\left(10 \% \mathrm{NH}_{4} \mathrm{OH}\right) / \mathrm{DCM}\right)$ to afford the title compound (62 $\left.\mathrm{mg}, 0.151 \mathrm{mmol}\right)$.

MS calculated for $\mathrm{C}_{25} \mathrm{H}_{23} \mathrm{~N}_{4} \mathrm{O}_{2}[\mathrm{M}+\mathrm{H}]^{+}:$411.2; found 411.0 (ESI+). 
Step 4: (S)-N-(4-((1-oxoisoindolin-2-yl)methyl)phenyl)-3-(pyridin-3-yl)pyrrolidine-1-carboxamide and (R)-N-(4-((1-oxoisoindolin-2-yl)methyl)phenyl)-3-(pyridin-3-yl)pyrrolidine-1-carboxamide

To a solution of $\mathrm{N}$-(4-((1-oxoisoindolin-2-yl)methyl)phenyl)-3-(pyridin-3-yl)-2,5-dihydro-1Hpyrrole-1-carboxamide (62 mg, $0.151 \mathrm{mmol})$ in $\mathrm{MeOH}(1.5 \mathrm{~mL})$ was added Pd-C (16.07 mg, 7.55 $\mu \mathrm{mol}) . \mathrm{H}_{2}$ was bubbled through the solution for $15 \mathrm{~min}$ and then the reaction was stirred under a ballon of hydrogen for 60 hours. The reaction was filtered on Celite $\AA$ and rinsed with $\mathrm{DCM} / \mathrm{MeOH}$. The mixture was concentrated and purified by reverse phase HPLC $\left(\mathrm{C}_{18}\right.$ X-Bridge 30x50mm 5 $\mu \mathrm{m}$ column, $25-50 \% \mathrm{MeCN} /$ water $\mathrm{w} / 5 \mathrm{mM} \mathrm{NH}_{4} \mathrm{OH}, 75 \mathrm{~mL} / \mathrm{min}$ ) to provide the racemic material. The enantiomers were then separated by chiral SFC (AS-H 21x250 mm, $5 \mu \mathrm{M} \mathrm{35 \%} \mathrm{MeOH} \mathrm{(10}$ $\left.\mathrm{mM} \mathrm{NH}{ }_{4} \mathrm{OH}, 80 \mathrm{~g} / \mathrm{min}\right)$. Compound 5 was the faster running enantiomer and Compound 6 was the slower running enantiomer.

Compound 5:

SFC Rt: $3.16 \mathrm{~min}$ (AS-H 4.6x100 mm, $5 \mu \mathrm{M}, 5-55 \% \mathrm{MeOH}\left(5 \mathrm{mM} \mathrm{NH} \mathrm{OH}_{4} / \mathrm{CO}_{2}, 5 \mathrm{~mL} / \mathrm{min}\right)$. MS calculated for $\mathrm{C}_{25} \mathrm{H}_{25} \mathrm{~N}_{4} \mathrm{O}_{2}[\mathrm{M}+\mathrm{H}]^{+}:$413.2; found 413.2 (ESI+).

H NMR (400 MHz, DMSO- $\left.d_{6}\right) \delta 8.55$ (d, J = 2.3 Hz, 1H), 8.46 (dd, J = 4.7, $\left.1.6 \mathrm{~Hz}, 1 \mathrm{H}\right), 8.19$ (s, $1 \mathrm{H}), 7.80-7.68(\mathrm{~m}, 2 \mathrm{H}), 7.63-7.53(\mathrm{~m}, 2 \mathrm{H}), 7.53-7.46(\mathrm{~m}, 3 \mathrm{H}), 7.41-7.34(\mathrm{~m}, 1 \mathrm{H}), 7.19-7.11(\mathrm{~m}$, $2 \mathrm{H}), 4.65(\mathrm{~s}, 2 \mathrm{H}), 4.35(\mathrm{~s}, 2 \mathrm{H}), 3.94-3.84(\mathrm{~m}, 1 \mathrm{H}), 3.68-3.59(\mathrm{~m}, 1 \mathrm{H}), 3.46-3.39(\mathrm{~m}, 1 \mathrm{H}), 3.35(\mathrm{~d}$, $\mathrm{J}=9.6 \mathrm{~Hz}, 1 \mathrm{H}), 2.33-2.25(\mathrm{~m}, 2 \mathrm{H}), 2.11-1.98(\mathrm{~m}, 1 \mathrm{H})$.

Compound 6:

SFC Rt: $3.40 \mathrm{~min}$ (AS-H 4.6x100 mm, $5 \mu \mathrm{M}, 5-55 \% \mathrm{MeOH}\left(5 \mathrm{mM} \mathrm{NH}_{4} \mathrm{OH}\right) / \mathrm{CO}_{2}, 5 \mathrm{~mL} / \mathrm{min}$ ). MS calculated for $\mathrm{C}_{25} \mathrm{H}_{25} \mathrm{~N}_{4} \mathrm{O}_{2}[\mathrm{M}+\mathrm{H}]^{+}:$413.2; found 413.2 (ESI+).

${ }^{1} \mathrm{H}$ NMR $\left(400 \mathrm{MHz}, \mathrm{DMSO}-\mathrm{d}_{6}\right) \delta 8.55(\mathrm{~d}, \mathrm{~J}=2.2 \mathrm{~Hz}, 1 \mathrm{H}), 8.46(\mathrm{dd}, \mathrm{J}=4.8,1.6 \mathrm{~Hz}, 1 \mathrm{H}), 8.19$ (s, $1 \mathrm{H}), 7.76(\mathrm{dt}, \mathrm{J}=8.0,2.1 \mathrm{~Hz}, 1 \mathrm{H}), 7.72(\mathrm{dt}, \mathrm{J}=7.5,1.0 \mathrm{~Hz}, 1 \mathrm{H}), 7.63-7.52(\mathrm{~m}, 2 \mathrm{H}), 7.53-7.46(\mathrm{~m}$, $3 \mathrm{H}), 7.37(\mathrm{~m}, 1 \mathrm{H}), 7.19-7.11(\mathrm{~m}, 2 \mathrm{H}), 4.65(\mathrm{~s}, 2 \mathrm{H}), 4.35(\mathrm{~s}, 2 \mathrm{H}), 3.89(\mathrm{dd}, \mathrm{J}=9.9,7.4 \mathrm{~Hz}, 1 \mathrm{H})$, $3.64(\mathrm{~m}, 1 \mathrm{H}), 3.44(\mathrm{~m}, 2 \mathrm{H}), 2.34-2.24(\mathrm{~m}, 2 \mathrm{H}), 2.10-1.97(\mathrm{~m}, 1 \mathrm{H})$

Compound 7: N-(4-((1-oxoisoindolin-2-yl)methyl)phenyl)-4-(pyridin-3-yl)piperidine-1carboxamide

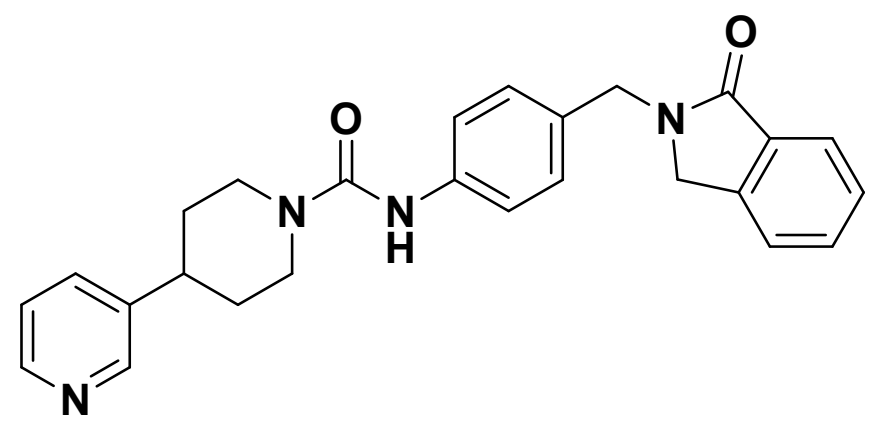


Step 1: tert-butyl 5',6'-dihydro-[3,4'-bipyridine]-1'(2'H)-carboxylate

To a solution of 3-bromopyridine (189 mg, $0.970 \mathrm{mmol}$ ) and tert-butyl 4-(4,4,5,5-tetramethyl-1,3,2dioxaborolan-2-yl)-5,6-dihydropyridine-1(2H)-carboxylate $(250 \mathrm{mg}, 0.809 \mathrm{mmol})$ in $\mathrm{MeCN}(8.0$ $\mathrm{mL}$ ) and $2 \mathrm{M} \mathrm{K}_{3} \mathrm{PO}_{4}\left(2.0 \mathrm{~mL}, 4.04 \mathrm{mmol}\right.$ ) was added $\mathrm{PdCl}_{2}(\mathrm{dppf})$ (23.66 mg, $0.032 \mathrm{mmol}$ ). Nitrogen was bubbled through the reaction for 10 minutes and then it was stirred at $110{ }^{\circ} \mathrm{C}$ in the microwave for 1 hour. The reaction was extracted with EtOAc $(3 \times 25 \mathrm{~mL})$ and the organics were washed with water $(1 \times 10 \mathrm{~mL})$ and brine $(1 \times 10 \mathrm{~mL})$, dried with sodium sulfate, filtered and concentrated. The crude was purified by FCC (30-70\% EtOAc/heptanes) to give the title compound (169 mg, 0.649 $\mathrm{mmol})$.

MS calculated for $\mathrm{C}_{15} \mathrm{H}_{21} \mathrm{~N}_{2} \mathrm{O}_{2}[\mathrm{M}+\mathrm{H}]^{+}:$261.2; found 261.3 (ESI+).

Step 2: tert-butyl 4-(pyridin-3-yl)piperidine-1-carboxylate

To a solution of tert-butyl 5',6'-dihydro-[3,4'-bipyridine]-1'(2'H)-carboxylate (169 mg, $0.649 \mathrm{mmol}$ ) in $\mathrm{EtOH}(3.2 \mathrm{~mL})$ was added $10 \% \mathrm{Pd}-\mathrm{C}(69.1 \mathrm{mg}, 0.032 \mathrm{mmol}) . \mathrm{H}_{2}$ was bubbled throught the solution for 5 minutes and then the reaction was stirred under a balloon of hydrogen for 90 minutes. The reaction was filtered over Celite ${ }$ and washed with $\mathrm{MeOH}$ and concentrated. The product was used directly in the next step.

MS calculated for $\mathrm{C}_{15} \mathrm{H}_{23} \mathrm{~N}_{2} \mathrm{O}_{2}[\mathrm{M}+\mathrm{H}]^{+:}$: 263.2; found 263.3 (ESI+).

Step 3: 3-(piperidin-4-yl)pyridine

To tert-butyl 4-(pyridin-3-yl)piperidine-1-carboxylate (158 mg, $0.602 \mathrm{mmol})$ in DCM $(0.5 \mathrm{~mL})$ was added $\mathrm{HCl} 4 \mathrm{~N}$ in dioxane $(3.0 \mathrm{~mL})$. The reaction was then stirred for 1 hour and concentrated and used directy in the next step.

MS calculated for $\mathrm{C}_{10} \mathrm{H}_{15} \mathrm{~N}_{2}[\mathrm{M}+\mathrm{H}]^{+}: 163.1$; found 163.3 (ESI+).

Step 4: $\quad$ N-(4-((1-oxoisoindolin-2-yl)methyl)phenyl)-4-(pyridin-3-yl)piperidine-1-carboxamide trifluroacetate

To a solution of 2-(4-aminobenzyl)isoindolin-1-one (50 mg, $0.210 \mathrm{mmol})$ and DIPEA (147 $\mu \mathrm{L}$, $0.839 \mathrm{mmol})$ in DCE $(1.0 \mathrm{~mL})$ was added phenyl chloroformate $(34.3 \mu \mathrm{L}, 0.273 \mathrm{mmol})$ at $0{ }^{\circ} \mathrm{C}$. The reaction was warmed to RT and stirred for 15 minutes. Then, 3-(piperidin-4-yl)pyridine (54.3 $\mathrm{mg}, 0.231 \mathrm{mmol}$ ) was added to the mixture and the reaction was stirred at $40{ }^{\circ} \mathrm{C}$ for 20 hours. Water $(20 \mathrm{~mL})$ was then added and the aqueous layerwas extracted with EtOAc $(3 \times 25 \mathrm{~mL})$. The combined organics were washed with brine $(1 \times 10 \mathrm{~mL})$, dried with sodium sulfate, filtered and concentrated. The crude was purified by RP-HPLC ( $\mathrm{C}_{18}$ Sunfire $30 \times 50 \mathrm{~mm} 5$ um column, $15-40 \%$ $\mathrm{MeCN} /$ water $(0.1 \% \mathrm{TFA}), 75 \mathrm{ml} / \mathrm{min}$ ) to afford the title compound (34 $\mathrm{mg}, 0.062 \mathrm{mmol}, 29.7 \%$ yield)

MS calculated for $\mathrm{C}_{26} \mathrm{H}_{27} \mathrm{~N}_{4} \mathrm{O}_{2}[\mathrm{M}+\mathrm{H}]^{+}:$427.2; found 427.2 (ESI+). 
1H NMR (400 MHz, DMSO-d6) ס $8.80(\mathrm{~s}, 1 \mathrm{H}), 8.76-8.65(\mathrm{~m}, 1 \mathrm{H}), 8.65-8.47(\mathrm{~m}, 1 \mathrm{H}), 8.35(\mathrm{~d}, \mathrm{~J}=$ $8.1 \mathrm{~Hz}, 1 \mathrm{H}), 7.85(\mathrm{dd}, \mathrm{J}=8.1,5.3 \mathrm{~Hz}, 1 \mathrm{H}), 7.72(\mathrm{~d}, \mathrm{~J}=7.5 \mathrm{~Hz}, 1 \mathrm{H}), 7.63-7.36(\mathrm{~m}, 5 \mathrm{H}), 7.16(\mathrm{~d}, \mathrm{~J}$ $=8.0 \mathrm{~Hz}, 3 \mathrm{H}), 6.82-6.63(\mathrm{~m}, 1 \mathrm{H}), 4.65(\mathrm{~s}, 2 \mathrm{H}), 4.34-4.25(\mathrm{~m}, 2 \mathrm{H}), 3.08-2.95(\mathrm{~m}, 1 \mathrm{H}), 2.89(\mathrm{t}, \mathrm{J}=$ $12.6 \mathrm{~Hz}, 2 \mathrm{H}), 1.96-1.76(\mathrm{~m}, 2 \mathrm{H}), 1.76-1.43(\mathrm{~m}, 2 \mathrm{H})$.

\section{Compound 16: 3-(azetidin-3-yl)pyridine hydrochloride}

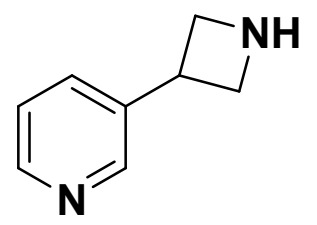

Step 1, Compound 11: tert-butyl 3-(pyridin-3-yl)azetidine-1-carboxylate:

To a suspension of zinc $(3.19 \mathrm{~g}, 48.8 \mathrm{mmol})$ in DMF $(10 \mathrm{~mL})$, iodine $(0.495 \mathrm{~g}, 1.951 \mathrm{mmol})$ was added at RT under nitrogen. The suspension changed from colorless to yellow and back again in 3 minutes. A solution of N-Boc-3-iodoazetidine $(3.04 \mathrm{~g}, 10.73 \mathrm{mmol})$ in DMF $(10 \mathrm{~mL})$ was transferred to the activated zinc via syringe. The reaction mixture was warmed up to $40{ }^{\circ} \mathrm{C}$ and incubated for 1 hour. Next, 3-iodopyridine $(2.00 \mathrm{~g}, 9.76 \mathrm{mmol}), \mathrm{Pd}_{2}\left(\mathrm{dba}_{3}{ }^{\circ} \mathrm{CHCl}_{3}\right.$ adduct $(0.505 \mathrm{~g}$, $0.488 \mathrm{mmol})$ and tri-o-tolylphosphine $(0.594 \mathrm{~g}, 1.951 \mathrm{mmol})$ were added successively under nitrogen. After stirring for $10 \mathrm{~min}$, the reaction was warmd up to $50^{\circ} \mathrm{C}$ and stirred for 90 minutes. The reaction mixture was cooled to RT, and filtered. The filter cake was washed with $\mathrm{MeOH}$. The combined organic layers were passed through a pad of silica gel and washed with $5 \% \mathrm{MeOH}$ in DCM and then the filtrate was concentrated. The residue was diluted with EtOAc $(200 \mathrm{~mL})$. The organic layer was washed with water $(2 \times 25 \mathrm{~mL})$ and then with brine $(1 \times 25 \mathrm{~mL})$, dried over $\mathrm{Na}_{2} \mathrm{SO}_{4}$, filtered and concentrated. The residue was purified twice by FCC (5-95\% MeOH/DCM) to give the title intermediate as a brown oil $(0.87 \mathrm{~g}, 3.71 \mathrm{mmol}, 38.1 \%$ yield $)$.

MS calculated for $\mathrm{C}_{13} \mathrm{H}_{19} \mathrm{~N}_{2} \mathrm{O}_{2}[\mathrm{M}+\mathrm{H}]^{+}: 235.1$; found 235.0 (ESI+).

${ }^{1} \mathrm{H}$ NMR (400 MHz, $\left.\mathrm{CDCl}_{3}\right) \delta 8.57-8.52(\mathrm{~m}, 2 \mathrm{H}), 7.73(\mathrm{dt}, \mathrm{J}=7.68,1.7 \mathrm{~Hz}, 1 \mathrm{H}), 7.32$ (ddd, J = 8.0, 4.8, $0.9 \mathrm{~Hz}, 1 \mathrm{H}), 4.37(\mathrm{t}, \mathrm{J}=8.7 \mathrm{~Hz}, 2 \mathrm{H}), 3.96(\mathrm{dd}, \mathrm{J}=8.7,5.8 \mathrm{~Hz}, 2 \mathrm{H}), 3.75(\mathrm{~m}, 1 \mathrm{H}), 1.47(\mathrm{~s}$, $9 \mathrm{H})$.

Step 2, 3-(azetidin-3-yl)pyridine hydrochloride:

tert-butyl 3-(pyridin-3-yl)azetidine-1-carboxylate $(438 \mathrm{mg}, 1.869 \mathrm{mmol}$ ) was dissolved in $\mathrm{MeOH}$ $(10 \mathrm{~mL})$. The reaction was cooled to $0^{\circ} \mathrm{C}$ and $4 \mathrm{~N} \mathrm{HCl}(20 \mathrm{~mL})$ in dioxane was added over about 3 minutes. The reaction was warmed to RT and stirred for 2 hours. The reaction was then concentrated on the rotovap and the resulting brown residue was taken up in $5 \mathrm{~mL}$ of $\mathrm{MeOH}$ and 
then $100 \mathrm{~mL}$ of diethyl ether was added. The resulting brown precipitate was isolated via Buchner filtration to yield the title compound (308 $\mathrm{mg}, 1.487 \mathrm{mmol})$.

MS calculated for $\mathrm{C}_{8} \mathrm{H}_{11} \mathrm{~N}_{2}[\mathrm{M}+\mathrm{H}]^{+}:$135.4; found 135.4 (ESI+).

${ }^{1} \mathrm{H}$ NMR (400 MHz, CD $\left.{ }_{3} \mathrm{OD}\right) \delta 8.99(\mathrm{~d}, \mathrm{~J}=2.0 \mathrm{~Hz}, 1 \mathrm{H}), 8.85(\mathrm{dt}, \mathrm{J}=5.8,1.0 \mathrm{~Hz}, 1 \mathrm{H}), 8.78(\mathrm{dt}, \mathrm{J}$ $=8.0,1.8 \mathrm{~Hz}, 1 \mathrm{H}), 8.16(\mathrm{dd}, \mathrm{J}=8.2,5.7 \mathrm{~Hz}, 1 \mathrm{H}), 4.63-4.37(\mathrm{~m}, 5 \mathrm{H})$.

${ }^{13} \mathrm{C}$ NMR (101 MHz, CD $\left.{ }_{3} \mathrm{OD}\right) \delta$ 146.63, 142.36, 142.16, 140.99, 128.72, 52.75, 34.99.

\section{Compound 17: 5-(azetidin-3-yl)pyridin-2-amine bis-trifluoroacetate}

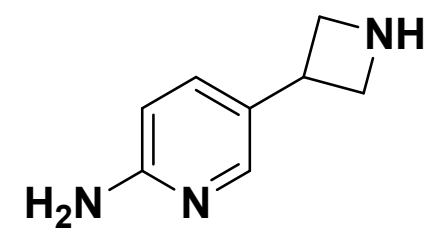

Step 1, Compound 12: tert-butyl 3-(6-chloropyridin-3-yl)azetidine-1-carboxylate

To a suspension of zinc $(1.15 \mathrm{~g}, 17.7 \mathrm{mmol})$ in DMF $(5 \mathrm{~mL})$, iodine (180 $\mathrm{mg}, 0.706 \mathrm{mmol})$ was added at RT under nitrogen. A solution of N-Boc-3-iodoazetidine $(1.0 \mathrm{~g}, 3.53 \mathrm{mmol})$ in DMF (5 $\mathrm{mL}$ ) was then added via syringe under nitrogen. After stirring at room temperature for 1 hour, 2chloro-5-iodopyridine $(0.930 \mathrm{~g}, 3.88 \mathrm{mmol}), \mathrm{Pd}_{2}(\mathrm{dba})_{3} \cdot \mathrm{CHCl}_{3}(0.161 \mathrm{~g}, 0.176 \mathrm{mmol})$ and tri(otolyl)phosphine $(0.11 \mathrm{~g}, 0.353 \mathrm{mmol})$ were added successively at room temperature under nitrogen. After stirring for 16 hours, the reaction mixture was filtered and the filter cake was washed with $\mathrm{MeOH}$. The organic layer was concentrated under reduced pressure and the residue taken up in EtOAc (100 mL) and washed with ice cold water. The aqueous layer was further extracted with EtOAc $(3 \times 20 \mathrm{~mL})$. The combined organic layers were dried over $\mathrm{Na}_{2} \mathrm{SO}_{4}$ and concentrated under reduced pressure. The crude material was purified by FCC (pet-ether/EtOAC $=9: 1)$ to give the title compound.

MS calculated for $\mathrm{C}_{13} \mathrm{H}_{18} \mathrm{CIN}_{2} \mathrm{O}_{2}[\mathrm{M}+\mathrm{H}]^{+}:$:269.1; found 269.0 (ESI+).

${ }^{1} \mathrm{H}$ NMR $\left(400 \mathrm{MHz}, \mathrm{CDCl}_{3}\right) \delta 8.29(\mathrm{~d}, \mathrm{~J}=2.4 \mathrm{~Hz}, 1 \mathrm{H}), 7.69(\mathrm{dd}, \mathrm{J}=2.4,2.8 \mathrm{~Hz}, 1 \mathrm{H}), 7.32(\mathrm{~d}, \mathrm{~J}=$ $8.4 \mathrm{~Hz}, 1 \mathrm{H}), 4.37(\mathrm{t}, \mathrm{J}=8.8 \mathrm{~Hz}, 2 \mathrm{H}), 3.93-3.89(\mathrm{~m}, 2 \mathrm{H}), 3.76-3.69(\mathrm{~m}, 1 \mathrm{H}), 1.47(\mathrm{~s}, 9 \mathrm{H})$; MS $(\mathrm{ESI}+) 269 \mathrm{~m} / \mathrm{z}(\mathrm{M}+\mathrm{H})$.

Step 2, Compound 14: tert-butyl 3-(6-aminopyridin-3-yl)azetidine-1-carboxylate

A suspension of tert-butyl 3-(6-chloropyridin-3-yl)azetidine-1-carboxylate $(0.440 \mathrm{~g}, 1.64 \mathrm{mmol})$, benzophenonimine $(0.356 \mathrm{~g}, 1.97 \mathrm{mmol})$, sodium tert-butoxide $(0.220 \mathrm{~g}, 2.29 \mathrm{mmol}), \mathrm{Pd}_{2}(\mathrm{dba})_{3}$ $(0.075 \mathrm{~g}, 0.08 \mathrm{mmol})$, rac-BINAP $(0.153 \mathrm{~g}, 0.24 \mathrm{mmol})$ in toluene $(5 \mathrm{~mL})$ was stirred at $100{ }^{\circ} \mathrm{C}$ for 3 hours. The reaction mixture was then cooled to room temperature and was concentrated under reduced pressure. The resulting crude tert-butyl 3-(6-((diphenylmethylene)amino)pyridin-3yl)azetidine-1-carboxylate was used without further purification in next step. To a solution of tert- 
butyl 3-(6-((diphenylmethylene)amino)pyridin-3-yl)azetidine-1-carboxylate (0.8 g, crude) in $\mathrm{MeOH}$ $(20 \mathrm{~mL})$ was added $50 \%$ hydroxylamine in water $(0.2 \mathrm{~mL})$ and the reaction was stirred at room temperature overnight. The reaction mixture was then concentrated under reduced pressure. The resulting crude oil was purified by FCC $(2 \% \mathrm{MeOH} / \mathrm{DCM})$ to give the title compound.

MS calculated for $\mathrm{C}_{13} \mathrm{H}_{20} \mathrm{~N}_{3} \mathrm{O}_{2}[\mathrm{M}+\mathrm{H}]^{+}: 250.2$; found $250.0(\mathrm{ESI}+)$.

${ }^{1} \mathrm{H} \mathrm{NMR}\left(400 \mathrm{MHz}, \mathrm{CDCl}_{3}\right) \delta 7.94(\mathrm{~d}, \mathrm{~J}=2 \mathrm{~Hz}, 1 \mathrm{H}), 7.48(\mathrm{dd}, \mathrm{J}=2.4,2.4 \mathrm{~Hz}, 1 \mathrm{H}), 6.53(\mathrm{~d}, \mathrm{~J}=$ $8.4 \mathrm{~Hz}, 1 \mathrm{H}), 4.37(\mathrm{br} \mathrm{s}, 2 \mathrm{H}), 4.29(\mathrm{t}, \mathrm{J}=8.8 \mathrm{~Hz}, 2 \mathrm{H}), 3.89-3.86(\mathrm{~m}, 2 \mathrm{H}), 3.65-3.59(\mathrm{~m}, 1 \mathrm{H}), 1.46$ (s, 9H).

Step 3, Compound 17: 5-(azetidin-3-yl)pyridin-2-amine bis-TFA salt

To a solution of tert-butyl 3-(6-aminopyridin-3-yl)azetidine-1-carboxylate $(0.100 \mathrm{~g}, 0.401 \mathrm{mmol})$ in DCM $(2 \mathrm{~mL})$ was added TFA $(1 \mathrm{~mL})$. The solution was stirred at room temperature for 3 hours. The reaction mixture was concentrated under reduced pressure and co-evaporated with toluene $(2 \times 5 \mathrm{~mL})$. The residue was washed with $\mathrm{Et} 2 \mathrm{O}(3 \times 5 \mathrm{~mL})$ to the title compound as bis-TFA salt. MS calculated for $\mathrm{C}_{8} \mathrm{H}_{12} \mathrm{~N}_{3}[\mathrm{M}+\mathrm{H}]^{+}$: 150.1 ; found $150.0(\mathrm{ESI}+)$.

${ }^{1} \mathrm{H}$ NMR (300 MHz, DMSO-d $\left.d_{6}\right) \delta 8.96$ (br s, 1H), 8.63 (br s, 1H), 7.96 (br s, 2H), 7.83 (br s, 1H), $6.93(\mathrm{~d}, \mathrm{~J}=9.6 \mathrm{~Hz}, 1 \mathrm{H}), 7.61(\mathrm{~m}, 1 \mathrm{H}), 4.17-4.05(\mathrm{~m}, 5 \mathrm{H})$.

\section{Compound 18: 5-(azetidin-3-yl)pyridin-3-amine bis-trifluoroacetate}

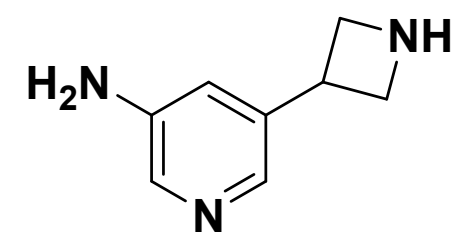

Step 1, Compound 13: tert-butyl 3-(5-bromopyridin-3-yl)azetidine-1-carboxylate

To a suspension of zinc $(2.29 \mathrm{~g}, 35.3 \mathrm{mmol})$ in DMF $(7 \mathrm{~mL})$, iodine $(0.360 \mathrm{~g}, 1.41 \mathrm{mmol})$ was added at room temperature under nitrogen. A solution of N-Boc-3-iodoazetidine $(2.0 \mathrm{~g}, 7.06$ $\mathrm{mmol})$ in DMF ( $7 \mathrm{~mL}$ ) was then added to the activated zinc via syringe under nitrogen. After stirring at room temperature for 1 hour, 3-bromo-5-iodopyridine $(2.2 \mathrm{~g}, 7.77 \mathrm{mmol}), \mathrm{Pd} 2(\mathrm{dba})_{3} \cdot \mathrm{CHCl}_{3}$ adduct $(368 \mathrm{mg}, 0.353 \mathrm{mmol}$ ) and tri-2-furylphosphine $(328 \mathrm{mg}, 1.41 \mathrm{mmol}$ ) were added successively at room temperature under nitrogen. After stirring for 16 hours the reaction mixture was filtered and the filter cake was washed with $\mathrm{MeOH}$. The organic layer was concentrated under reduced pressure. The residue was taken up in EtOAc $(250 \mathrm{~mL})$ and washed with ice cold water $(1 \times 50 \mathrm{~mL})$. The aqueous layer was further extracted with EtOAc $(3 \times 50 \mathrm{~mL})$ and the combined organic layers were dried over $\mathrm{Na}_{2} \mathrm{SO}_{4}$ and concentrated under reduced pressure. The crude material was purified by FCC (30\% EtOAc/petroleum ether) to give the title compound.

MS calculated for $\mathrm{C}_{13} \mathrm{H}_{18} \mathrm{BrN}_{2} \mathrm{O}_{2}[\mathrm{M}+\mathrm{H}]^{+}: 313.1$; found 313.1 (ESI+). 
${ }^{1} \mathrm{H}$ NMR $\left(400 \mathrm{MHz}, \mathrm{CD}_{3} \mathrm{OD}\right) \delta 8.56(\mathrm{~d}, \mathrm{~J}=2.2 \mathrm{~Hz}, 1 \mathrm{H}), 8.49(\mathrm{~d}, \mathrm{~J}=2.0 \mathrm{~Hz}, 1 \mathrm{H}), 8.11-8.02(\mathrm{~m}$, $1 \mathrm{H}), 4.37(\mathrm{t}, \mathrm{J}=8.5 \mathrm{~Hz}, 2 \mathrm{H}), 3.99-3.83(\mathrm{~m}, 3 \mathrm{H}), 1.47(\mathrm{~s}, 9 \mathrm{H})$.

Step 2, Compound 15: tert-butyl 3-(5-aminopyridin-3-yl)azetidine-1-carboxylate

A suspension of tert-butyl 3-(5-bromopyridin-3-yl)azetidine-1-carboxylate $(0.500 \mathrm{~g}, 1.59 \mathrm{mmol})$, benzophenonimine (347 mg, $1.91 \mathrm{mmol}$ ), sodium tert-butoxide (460 mg, $4.78 \mathrm{mmol}), \mathrm{Pd}_{2}(\mathrm{dba})_{3}$ (73 mg, $0.08 \mathrm{mmol})$, rac-BINAP (150 mg, $0.24 \mathrm{mmol})$ in toluene $(6 \mathrm{~mL})$ was stirred at $100{ }^{\circ} \mathrm{C}$ for 2 hours. The reaction mixture was then cooled to room temperature and was concentrated under reduced pressure. The resulting crude oil tert-butyl 3-(5-((diphenylmethylene)amino)pyridin-3$\mathrm{yl})$ azetidine-1-carboxylate was used without further purification in next step. To a solution of tertbutyl 3-(5-((diphenylmethylene)amino)pyridin-3-yl)azetidine-1-carboxylate (659 mg, crude) in $\mathrm{MeOH}(17 \mathrm{~mL})$ was added $50 \%$ hydroxylamine in water $(0.26 \mathrm{~mL})$ and the reaction was stirred at room temperature overnight. Another portion of $50 \%$ hydroxylamine in water $(0.5 \mathrm{~mL})$ was added and the reaction was stirred further for $4 \mathrm{~h}$. The reaction was then concentrated under reduced pressure. The resulting crude oil was purified by FCC ( $5 \% \mathrm{MeOH} / \mathrm{DCM})$ to give the title compound (380 mg, 90\%).

MS calculated for $\mathrm{C}_{13} \mathrm{H}_{19} \mathrm{~N}_{3} \mathrm{O}_{2}[\mathrm{M}+\mathrm{H}]^{+}:$250.1, found; 250.0 (ESI+)

${ }^{1} \mathrm{H}$ NMR (400 MHz, CDCl $): \delta 7.81(\mathrm{~d}, \mathrm{~J}=2.4 \mathrm{~Hz}, 1 \mathrm{H}), 7.64(\mathrm{~d}, \mathrm{~J}=2 \mathrm{~Hz}, 1 \mathrm{H}), 6.93(\mathrm{~s}, 1 \mathrm{H}), 5.30$ (br s, 2H), $4.22(\mathrm{t}, \mathrm{J}=8.4 \mathrm{~Hz}, 2 \mathrm{H}), 3.72(\mathrm{t}, \mathrm{J}=6 \mathrm{~Hz}, 2 \mathrm{H}), 3.66-3.62(\mathrm{~m}, 1 \mathrm{H}), 1.40(\mathrm{~s}, 9 \mathrm{H})$.

Step 3, Compound 18: 5-(azetidin-3-yl)pyridin-3-amine bis-trifluoroacetate

To a solution of tert-butyl 3-(5-aminopyridin-3-yl)azetidine-1-carboxylate (380 mg, $1.53 \mathrm{mmol}$ ) in $\mathrm{DCM}(4 \mathrm{~mL})$ at $0{ }^{\circ} \mathrm{C}$ was added TFA $(1 \mathrm{~mL})$. After stirring at room temperature for 2 hours the reaction mixture was concentrated under reduced pressure. The residue was washed with $\mathrm{Et}_{2} \mathrm{O}$ $(3 \times 15 \mathrm{~mL})$ to afford the title compound (450 $\mathrm{mg}, 86 \%)$.

MS calculated for $\mathrm{C}_{8} \mathrm{H}_{11} \mathrm{~N}_{3}[\mathrm{M}+\mathrm{H}]^{+}:$150.1, found; 150.0 (ESI+)

${ }^{1} \mathrm{H}$ NMR (300 MHz, DMSO-d 6 ) $\delta 9.09$ (br s, 1H), 8.78 (br s, 1H), 8.03 (br s, 2H), 7.42 (br s, 1H), 4.24- $4.10(\mathrm{~m}, 5 \mathrm{H})$.

\section{Compound 20a: (S)-2-(1-(4-nitrophenyl)ethyl)isoindolin-1-one}

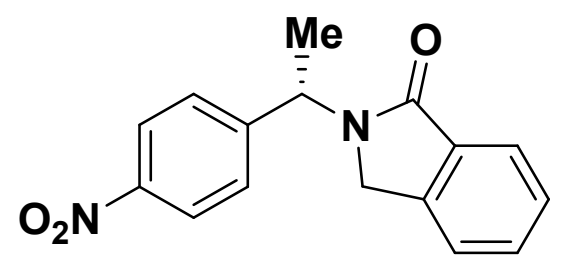

To a suspension of $(S)-1$-(4-nitrophenyl)ethanamine $(1.0 \mathrm{~g}, 4.93 \mathrm{mmol})$, DIEA (1.72 mL, 9.87 $\mathrm{mmol})$, and sodium triacetoxyborohydride $(5.23 \mathrm{~g}, 24.7 \mathrm{mmol})$ in DCE $(40 \mathrm{~mL})$ at room temperature was added methyl 2-formylbenzoate $(5.67 \mathrm{~g}, 34.5 \mathrm{mmol}, \sim 60 \%)$. The mixture was 
left stirring overnight. At that time the reaction was diluted with DCM $(100 \mathrm{~mL})$ and washed with sat. aq. $\mathrm{NaHCO}_{3}(3 \times 25 \mathrm{~mL})$. The aqueous layer was further extracted with $\mathrm{DCM}(2 \times 25 \mathrm{~mL})$ and the combined organic layers were the dried over sodium sulfate, filtered and concentrated under reduced pressure. The residue was then purified by FCC (10-60\% EtOAc/heptane) to give the title compound $(1.30 \mathrm{~g}, 4.61 \mathrm{mmol})$.

MS calculated for $\mathrm{C}_{16} \mathrm{H}_{15} \mathrm{~N}_{2} \mathrm{O}_{3}[\mathrm{M}+\mathrm{H}]^{+}:$:283.1; found 283.1 (ESI+).

${ }^{1} \mathrm{H}$ NMR $\left(400 \mathrm{MHz}\right.$, DMSO- $\left.d_{6}\right) \delta 8.26-8.16(\mathrm{~m}, 2 \mathrm{H}), 7.71(\mathrm{~d}, \mathrm{~J}=7.5 \mathrm{~Hz}, 1 \mathrm{H}), 7.65-7.55(\mathrm{~m}$, 4H), $7.54-7.47(\mathrm{~m}, 1 \mathrm{H}), 5.60(\mathrm{q}, \mathrm{J}=7.2 \mathrm{~Hz}, 1 \mathrm{H}), 4.60(\mathrm{~d}, \mathrm{~J}=17.6 \mathrm{~Hz}, 1 \mathrm{H}), 4.27$ (d, J = $17.6 \mathrm{~Hz}$, $1 \mathrm{H}), 1.70(\mathrm{~d}, \mathrm{~J}=7.2 \mathrm{~Hz}, 3 \mathrm{H})$.

\section{Compound 20b: (S)-3-fluoro-N-(1-(4-nitrophenyl)ethyl)benzamide}<smiles>CC(NC(=O)c1cccc(F)c1)c1ccc([N+](=O)[O-])cc1</smiles>

To a solution of $(S)$-1-(4-nitrophenyl)ethanamine $(85 \mathrm{mg}, 0.419 \mathrm{mmol})$ and $\mathrm{Et}_{3} \mathrm{~N}(145 \mu \mathrm{l}, 1.049$ $\mathrm{mmol})$ in DCM $(2.8 \mathrm{~mL})$ was added 3-fluorophenylbenzoyl chloride $(66 \mu \mathrm{L}, 0.545 \mathrm{mmol})$ at $0{ }^{\circ} \mathrm{C}$. The reaction was warmed to room temperature and stirred for 2 hours. The reaction was poured into a solution of sat. aq. $\mathrm{NH}_{4} \mathrm{Cl}(25 \mathrm{~mL})$ and extracted with EtOAc $(3 \times 25 \mathrm{~mL})$. The organics phases were combined, washed with brine $(1 \times 10 \mathrm{~mL})$, dried with sodium sulfate, filtered and concentrated to yield the title compound $(93 \mathrm{mg}, 0.323 \mathrm{mmol}$ ) as a white solid that was used without further purification.

MS calculated for $\mathrm{C}_{15} \mathrm{H}_{14} \mathrm{FN}_{2} \mathrm{O}_{3}[\mathrm{M}+\mathrm{H}]^{+}:$289.1; found 289.2 (ESI+).

The following compounds were prepared in an analogus manner using the relevant starting material:

\begin{tabular}{|c|c|c|}
\hline Compound & Structure & $\begin{array}{l}\text { Chemical name and } \\
\text { analytical data }\end{array}$ \\
\hline $20 d$ & & $\begin{array}{l}\text { (S)-N-(1-(4- } \\
\text { nitrophenyl)ethyl)tetrahydro- } \\
2 \mathrm{H}-\text { pyran-4-carboxamide } \\
\mathrm{MS}(\mathrm{ESI}+) 279.3 \mathrm{~m} / \mathrm{z}[\mathrm{M}+\mathrm{H}]^{+}\end{array}$ \\
\hline
\end{tabular}




\begin{tabular}{|l|l|l|}
\hline $20 f$ & $\begin{array}{l}(\mathrm{S})-\mathrm{N}-(1-(4- \\
\text { nitrophenyl)ethyl)propionamide } \\
\mathrm{MS}(\mathrm{ESI}+) 223.2 \mathrm{~m} / \mathrm{z}[\mathrm{M}+\mathrm{H}]^{+}\end{array}$ \\
\hline
\end{tabular}

Compound 20c: (S)-N-(1-(4-nitrophenyl)ethyl)pyrimidine-2-carboxamide<smiles>CC(NC(=O)c1ncccn1)c1ccc([N+](=O)[O-])cc1</smiles>

pyrimidine-2-carboxylic acid (245 mg, $1.974 \mathrm{mmol}$ ) and HATU (1126 mg, $2.96 \mathrm{mmol}$ ) were dissolevd in THF $(10 \mathrm{~mL})$ and cooled to $0{ }^{\circ} \mathrm{C}$. The reaction was stirred for 10 minutes and then DIPEA (1.0 mL, $5.92 \mathrm{mmol})$ was added. The reaction was stirred for another 10 minutes and then (S)-1-(4-nitrophenyl)ethanamine $(400 \mathrm{mg}, 1.974 \mathrm{mmol}$ ) of the amine was added. The reaction was warmed to RT and stirred for 16 hours. The reaction was poured into a $250 \mathrm{~mL}$ sep funnel and diluted with EtOAc $(150 \mathrm{~mL})$. The organic phase was washed with $1 \mathrm{~N} \mathrm{HCl}(5 \times 10 \mathrm{~mL})$ and brine $(1 \times 10 \mathrm{~mL})$, dried over $\mathrm{MgSO}_{4}$ filtered and concentrated. The material was then purified by FCC $(0-5 \% \mathrm{MeOH} / \mathrm{DCM})$ to yield the title compound (426 mg, $79 \%)$.

MS (ESI+) $273.0 \mathrm{~m} / \mathrm{z}[\mathrm{M}+\mathrm{H}]^{+}$.

${ }^{1} \mathrm{H}$ NMR $\left(400 \mathrm{MHz}, \mathrm{CDCl}_{3}\right) \delta 8.90(\mathrm{~d}, \mathrm{~J}=4.7 \mathrm{~Hz}, 2 \mathrm{H}), 8.42-8.29(\mathrm{~m}, 1 \mathrm{H}), 8.28-8.16(\mathrm{~m}, 2 \mathrm{H})$, $7.66-7.56(\mathrm{~m}, 2 \mathrm{H}), 7.49(\mathrm{t}, \mathrm{J}=5.0 \mathrm{~Hz}, 1 \mathrm{H}), 5.49(\mathrm{p}, \mathrm{J}=7.1 \mathrm{~Hz}, 1 \mathrm{H}), 1.69(\mathrm{~d}, \mathrm{~J}=7.0 \mathrm{~Hz}, 3 \mathrm{H})$.

The following compounds were prepared in an analogus manner using the relevant starting material:

\begin{tabular}{|l|c|l|}
\hline Compound & Structure & \multicolumn{1}{c|}{$\begin{array}{c}\text { Chemical name and } \\
\text { analytical data }\end{array}$} \\
\hline $20 \mathrm{e}$ & & $\begin{array}{l}\text { (S)-1-methyl-N-((S)-1-(4- } \\
\text { nitrophenyl)ethyl)pyrrolidine-2- } \\
\text { carboxamide } \\
\mathrm{MS}(\mathrm{ESI}+) 278.1 \mathrm{~m} / \mathrm{z}[\mathrm{M}+\mathrm{H}]^{+}\end{array}$ \\
\hline
\end{tabular}

Compound SI-1: 3-(4-nitrobenzyl)benzo[d]oxazol-2(3H)-one 
<smiles>O=c1oc2ccccc2n1Cc1ccc([N+](=O)[O-])cc1</smiles>

A suspension of 4-nitrobenzyl bromide ( $576 \mathrm{mg}, 2.66 \mathrm{mmol}$ ), 2-benzoxazolidinone ( $300 \mathrm{mg}, 2.220$ $\mathrm{mmol}$ ) and $\mathrm{K}_{2} \mathrm{CO}_{3}(460 \mathrm{mg}, 3.33 \mathrm{mmol})$ in DMF $(5 \mathrm{~mL})$ was stirred at $50{ }^{\circ} \mathrm{C}$ under nitrogen. After stirring for 2 hours, the reaction mixture was cooled to RT and diluted with $\mathrm{H}_{2} \mathrm{O}(50 \mathrm{~mL})$. The precipitated solid was collected on a Kiriyama funnel, washed with $\mathrm{MeOH} / \mathrm{H}_{2} \mathrm{O}(1: 20)$ and dried under reduced pressure to give the title intermediate $(600 \mathrm{mg}, 2.220 \mathrm{mmol})$ as a white solid that was used without further purification.

MS (ESI+) $270.9 \mathrm{~m} / \mathrm{z}[\mathrm{M}+\mathrm{H}]^{+}$.

The following compounds were prepared in an analogus manner using the relevant starting material:

\begin{tabular}{|l|l|l|}
\hline Compound & \multicolumn{1}{c|}{$\begin{array}{c}\text { Chemical name and } \\
\text { analytical data }\end{array}$} \\
\hline 2-methoxy-1-(4-nitrobenzyl)- \\
\hline SI-4
\end{tabular}

Compound 21a: (S)-2-(1-(4-aminophenyl)ethyl)isoindolin-1-one 
<smiles>CC(c1ccc(N)cc1)N1Cc2ccccc2C1=O</smiles>

A mixture of $(S)-2-(1-(4-n i t r o p h e n y l) e t h y l)$ isoindolin-1-one $(0.121 \mathrm{~g}, 0.429 \mathrm{mmol})$, zinc $(0.140 \mathrm{~g}$, $2.14 \mathrm{mmol})$, ammonium chloride $(0.115 \mathrm{~g}, 2.14 \mathrm{mmol})$, water $(2 \mathrm{~mL})$, and ethanol $(5 \mathrm{~mL})$ was heated at $50{ }^{\circ} \mathrm{C}$ for 2 hours. The mixture was then filtered over celite and the filtrate was concentrated under reduced pressure. The residue was taken up in EtOAc $(150 \mathrm{~mL})$ and washed with water $(2 \times 25 \mathrm{~mL})$. The aqueous layer was further extracted with EtOAc $(2 \times 25 \mathrm{~mL})$ and the combined organic layers were dried over sodium sulfate, filtered and concentrated to give the title compound, which was used without further purification (110 mg, $0.392 \mathrm{mmol}$ ).

MS (ESI+) $253.2 \mathrm{~m} / \mathrm{z}[\mathrm{M}+\mathrm{H}]^{+}$.

${ }^{1} \mathrm{H}$ NMR (400 MHz, DMSO- $\left.d_{6}\right) \delta 7.68(\mathrm{~d}, \mathrm{~J}=7.5 \mathrm{~Hz}, 1 \mathrm{H}), 7.59-7.50(\mathrm{~m}, 2 \mathrm{H}), 7.50-7.44(\mathrm{~m}$, $1 \mathrm{H}), 6.99(\mathrm{~d}, \mathrm{~J}=8.3 \mathrm{~Hz}, 2 \mathrm{H}), 6.54(\mathrm{~d}, \mathrm{~J}=8.3 \mathrm{~Hz}, 2 \mathrm{H}), 5.39(\mathrm{q}, \mathrm{J}=7.1 \mathrm{~Hz}, 1 \mathrm{H}), 5.02(\mathrm{~s}, 2 \mathrm{H}), 4.44$ $(\mathrm{d}, \mathrm{J}=17.8 \mathrm{~Hz}, 1 \mathrm{H}), 3.98(\mathrm{~d}, \mathrm{~J}=17.8 \mathrm{~Hz}, 1 \mathrm{H}), 1.54(\mathrm{~d}, \mathrm{~J}=7.1 \mathrm{~Hz}, 3 \mathrm{H})$.

The following compounds were prepared in an analogus manner using the relevant starting material:

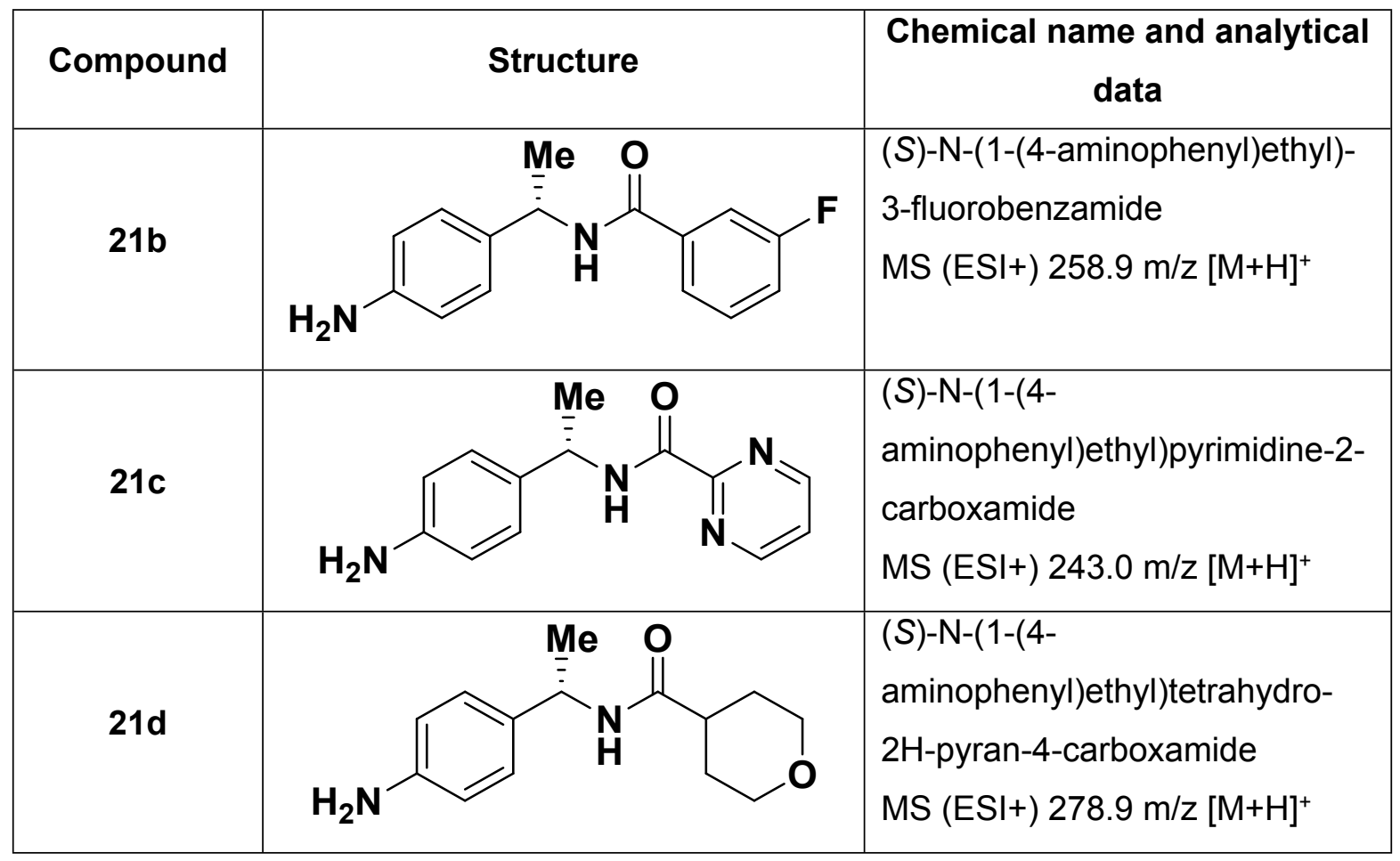




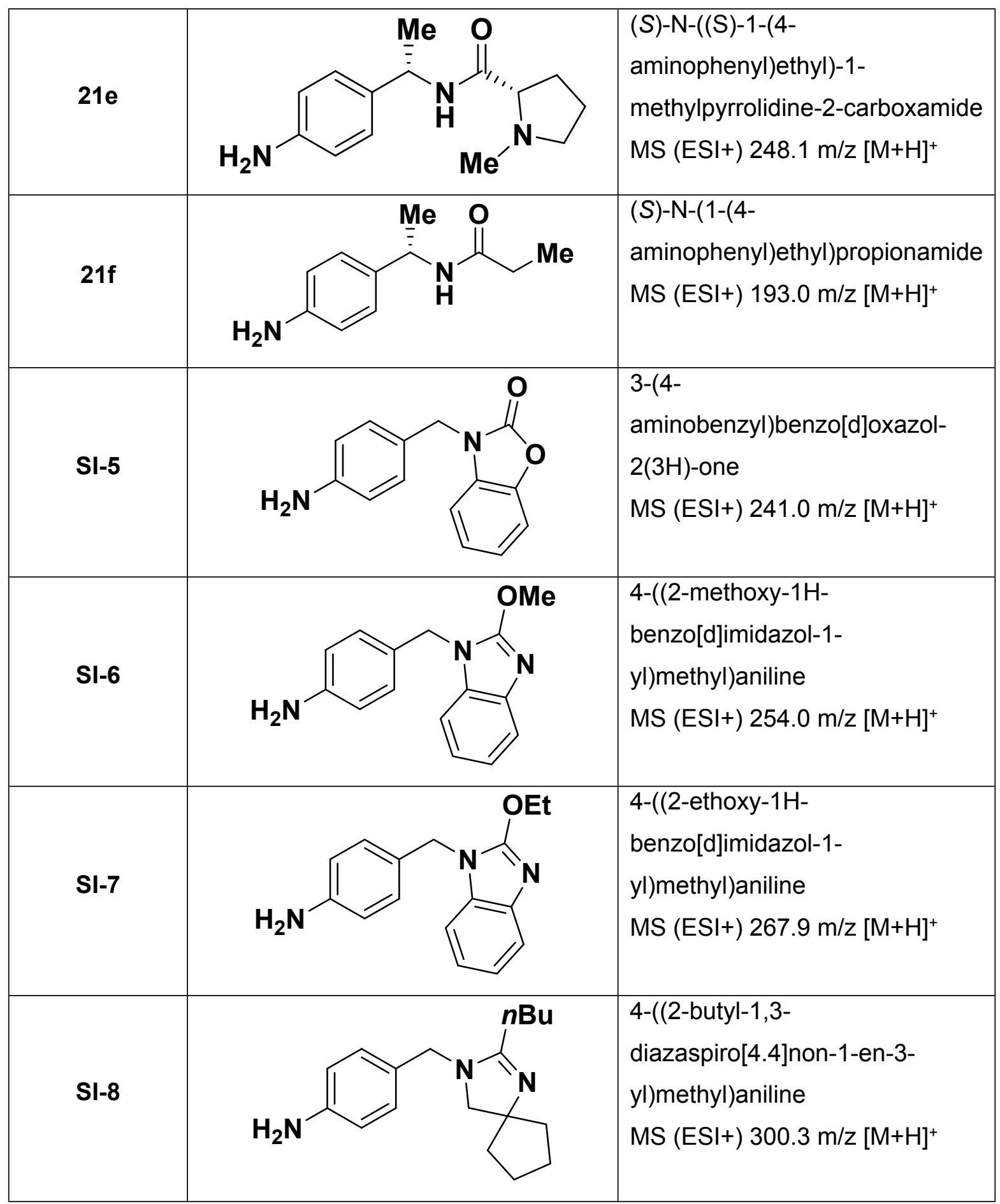

Compound 22a: (S)-N-(4-(1-(1-oxoisoindolin-2-yl)ethyl)phenyl)-3-(pyridin-3-yl)azetidine-1carboxamide 


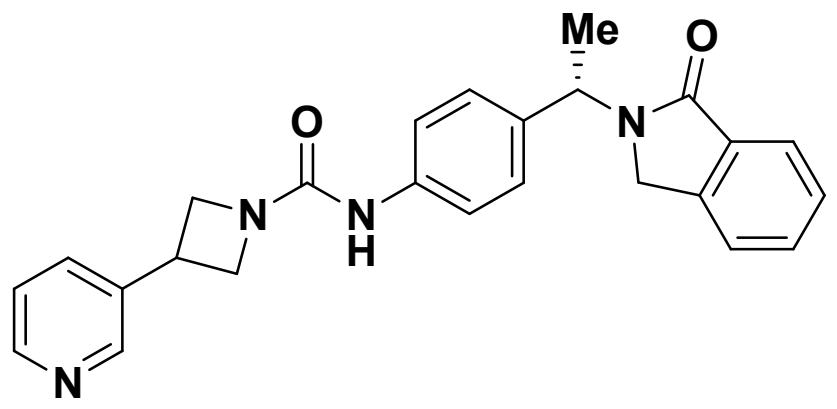

To a solution of (S)-2-(1-(4-aminophenyl)ethyl)isoindolin-1-one (40 mg, $0.159 \mathrm{mmol}$ ) and DIPEA $(110 \mu \mathrm{L}, 0.634 \mathrm{mmol})$ in DCE $(0.8 \mathrm{~mL})$ was added phenyl chloroformate $(24 \mu \mathrm{L}, 0.190 \mathrm{mmol})$ at $0{ }^{\circ} \mathrm{C}$. After $30 \mathrm{~min}$, 3-(azetidin-3-yl)pyridine $\cdot 2 \mathrm{HCl}(36.1 \mathrm{mg}, 0.174 \mathrm{mmol})$ was added to the mixture. After $15 \mathrm{~min}$, the resulting solution was heated at $40{ }^{\circ} \mathrm{C}$ for 16 hours. The reaction was cooled to room temperature and was then and concentrated under reduced pressure. The residue was then purified by $\mathrm{FCC}\left(1-10 \% \mathrm{MeOH}\left(10 \% \mathrm{NH}_{4} \mathrm{OH}\right) / \mathrm{DCM}\right)$. Further purification by semi-prep HPLC $\left(\mathrm{C}_{18}\right.$ X-Bridge 30x50mm 5um column, 15\%- 40\% MeCN/water (5mM NH4OH), $75 \mathrm{~mL} / \mathrm{min}$ ) provided the title compound.

MS (ESI+) $413.2 \mathrm{~m} / \mathrm{z}[\mathrm{M}+\mathrm{H}]^{+}$.

${ }^{1} \mathrm{H}$ NMR (400 MHz, DMSO- $\left.d_{6}\right) \delta$ 8.59-8.52 (m, 2H), 8.50-8.44 (m, 1H), 7.86 (dt, J = 7.9, 2.0 Hz, $1 \mathrm{H}), 7.70(\mathrm{~d}, \mathrm{~J}=7.5 \mathrm{~Hz}, 1 \mathrm{H}), 7.61-7.52(\mathrm{~m}, 2 \mathrm{H}), 7.52-7.44(\mathrm{~m}, 3 \mathrm{H}), 7.40(\mathrm{~m}, 1 \mathrm{H}), 7.22(\mathrm{~d}, \mathrm{~J}=8.6$ $\mathrm{Hz}, 2 \mathrm{H}), 5.48(\mathrm{q}, \mathrm{J}=7.1 \mathrm{~Hz}, 1 \mathrm{H}), 4.50(\mathrm{~d}, \mathrm{~J}=17.7 \mathrm{~Hz}, 1 \mathrm{H}), 4.42-4.33(\mathrm{~m}, 2 \mathrm{H}), 4.05(\mathrm{~d}, \mathrm{~J}=17.7$ $\mathrm{Hz}, 1 \mathrm{H}), 3.99-3.92(\mathrm{~m}, 2 \mathrm{H}), 3.91-3.80(\mathrm{~m}, 1 \mathrm{H}), 1.60(\mathrm{~d}, \mathrm{~J}=7.1 \mathrm{~Hz}, 3 \mathrm{H})$.

The following compounds were synthesized via a similar procedure using the relevant starting materials:

\begin{tabular}{|c|l|}
\hline Compound & Name and analytical data \\
\hline $22 b$ & $\begin{array}{l}1 \mathrm{H} N \mathrm{NMR}\left(400 \mathrm{MHz}, \mathrm{DMSO}-\mathrm{d}_{6}\right) \delta 8.80(\mathrm{~d}, \mathrm{~J}=8.0 \mathrm{~Hz}, 1 \mathrm{H}), 8.56(\mathrm{~d}, \mathrm{~J}=2.3 \mathrm{~Hz}, 1 \mathrm{H}), \\
8.51-8.43(\mathrm{~m}, 2 \mathrm{H}), 7.86(\mathrm{dt}, \mathrm{J}=7.8,2.0 \mathrm{~Hz}, 1 \mathrm{H}), 7.74(\mathrm{~d}, \mathrm{~J}=7.7 \mathrm{~Hz}, 1 \mathrm{H}), 7.71- \\
7.64(\mathrm{~m}, 1 \mathrm{H}), 7.52(\mathrm{td}, \mathrm{J}=8.0,5.8 \mathrm{~Hz}, 1 \mathrm{H}), 7.47-7.33(\mathrm{~m}, 4 \mathrm{H}), 7.26(\mathrm{~d}, \mathrm{~J}=8.3 \\
\mathrm{Hz}, 2 \mathrm{H}), 5.17-5.05(\mathrm{~m}, 1 \mathrm{H}), 4.37(\mathrm{t}, \mathrm{J}=8.3 \mathrm{~Hz}, 2 \mathrm{H}), 3.95(\mathrm{dd}, \mathrm{J}=8.0,5.9 \mathrm{~Hz},\end{array}$ \\
\hline
\end{tabular}




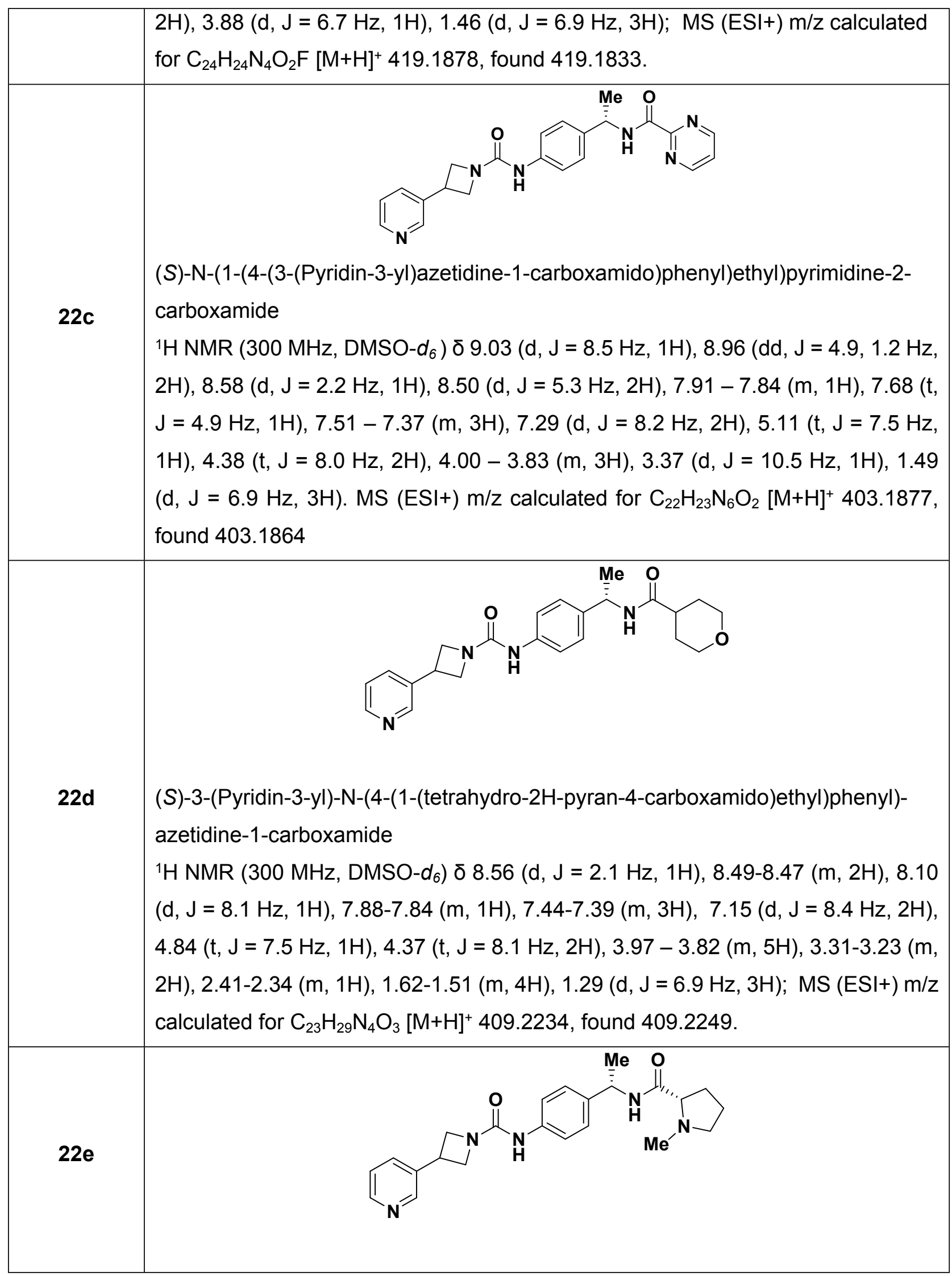




\begin{tabular}{|c|c|}
\hline & 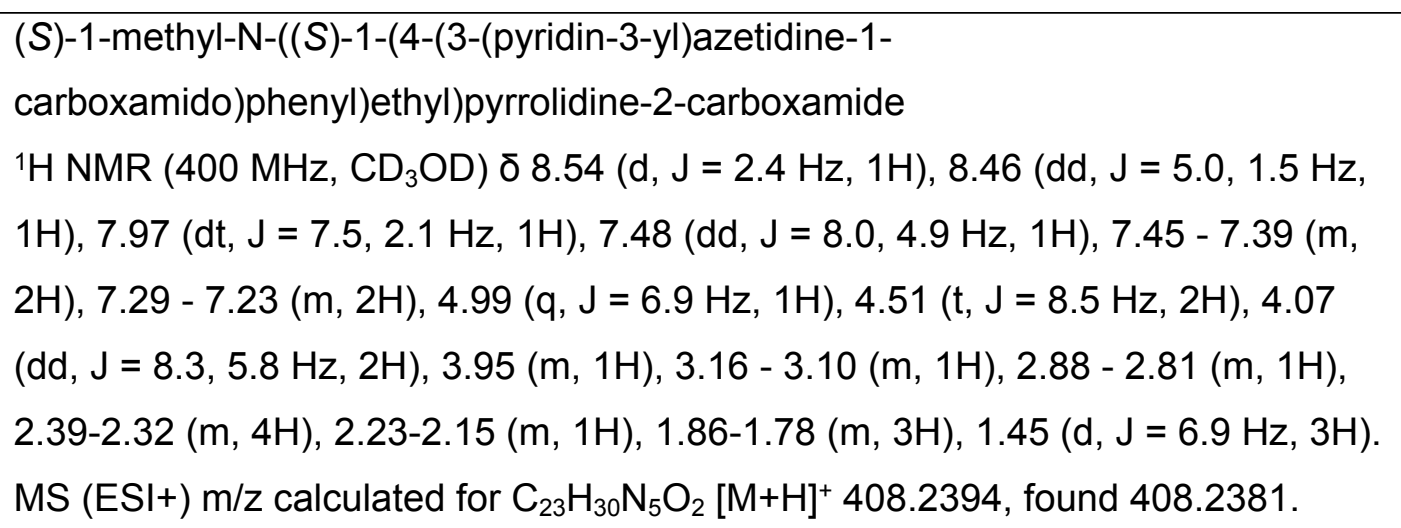 \\
\hline $22 f$ & $\begin{array}{l}\text { (S)-N-(4-(1-propionamidoethyl)phenyl)-3-(pyridin-3-yl)azetidine-1-carboxamide } \\
1 \mathrm{H} \mathrm{NMR}\left(400 \mathrm{MHz}, \mathrm{DMSO}-\mathrm{d}_{6}\right) \delta 8.56(\mathrm{~d}, \mathrm{~J}=2.1 \mathrm{~Hz}, 1 \mathrm{H}), 8.52-8.44(\mathrm{~m}, 2 \mathrm{H}), 8.07 \\
(\mathrm{~d}, \mathrm{~J}=8.1 \mathrm{~Hz}, 1 \mathrm{H}), 7.86(\mathrm{dt}, \mathrm{J}=8.0,1.9 \mathrm{~Hz}, 1 \mathrm{H}), 7.47-7.36(\mathrm{~m}, 3 \mathrm{H}), 7.16(\mathrm{~d}, \mathrm{~J}= \\
8.5 \mathrm{~Hz}, 2 \mathrm{H}), 4.85(\mathrm{p}, \mathrm{J}=7.3 \mathrm{~Hz}, 1 \mathrm{H}), 4.37(\mathrm{t}, \mathrm{J}=8.3 \mathrm{~Hz}, 2 \mathrm{H}), 4.00-3.92(\mathrm{~m}, 2 \mathrm{H}) \text {, } \\
\text { 3.92-3.79 }(\mathrm{m}, 1 \mathrm{H}), 2.10(\mathrm{q}, \mathrm{J}=7.7 \mathrm{~Hz}, 2 \mathrm{H}), 1.30(\mathrm{~d}, \mathrm{~J}=6.9 \mathrm{~Hz}, 3 \mathrm{H}), 0.98(\mathrm{t}, \mathrm{J}=7.6 \\
\mathrm{Hz}, 3 \mathrm{H}) ; \mathrm{MS}(\mathrm{ESI}+) \mathrm{m} / \mathrm{z} \text { calculated for } \mathrm{C}_{20} \mathrm{H}_{25} \mathrm{~N}_{4} \mathrm{O}_{2}[\mathrm{M}+\mathrm{H}]^{+} 353.1978 \text {, found } \\
\text { 353.1971. }\end{array}$ \\
\hline $23 a$ & $\begin{array}{l}\text { (S)-3-(6-Aminopyridin-3-yl)-N-(4-(1-(1-oxoisoindolin-2-yl)ethyl)phenyl)azetidine-1- } \\
\text { carboxamide } \\
{ }^{1} \mathrm{H} \mathrm{NMR}\left(400 \mathrm{MHz}, \mathrm{DMSO}-\mathrm{d}_{6}\right) \delta 8.48(\mathrm{~s}, 1 \mathrm{H}), 7.85(\mathrm{~d}, \mathrm{~J}=2.0 \mathrm{~Hz}, 1 \mathrm{H}), 7.69(\mathrm{~d}, \mathrm{~J} \\
=7.6 \mathrm{~Hz}, 1 \mathrm{H}), 7.63(\mathrm{~d}, \mathrm{~J}=9.2 \mathrm{~Hz}, 1 \mathrm{H}), 7.57-7.53(\mathrm{~m}, 2 \mathrm{H}), 7.49-7.46(\mathrm{~m}, 3 \mathrm{H}), \\
7.21(\mathrm{~d}, \mathrm{~J}=8.4 \mathrm{~Hz}, 2 \mathrm{H}), 6.62(\mathrm{~d}, \mathrm{~J}=8.8 \mathrm{~Hz}, 1 \mathrm{H}), 6.43(\mathrm{br} \mathrm{s}, 2 \mathrm{H}), 5.47(\mathrm{q}, \mathrm{J}=7.2 \\
\mathrm{Hz}, 1 \mathrm{H}), 4.49(\mathrm{~d}, \mathrm{~J}=17.6 \mathrm{~Hz}, 1 \mathrm{H}), 4.27(\mathrm{t}, \mathrm{J}=8.4 \mathrm{~Hz}, 2 \mathrm{H}), 4.04(\mathrm{~d}, \mathrm{~J}=18.0 \mathrm{~Hz} \text {, } \\
\text { 1H), } 3.86-3.82(\mathrm{~m}, 2 \mathrm{H}), 3.68(\mathrm{t}, 1 \mathrm{H}), 1.60(\mathrm{~d}, \mathrm{~J}=7.2 \mathrm{~Hz}, 3 \mathrm{H}) . \mathrm{MS}(\mathrm{ESI}+) \mathrm{m} / \mathrm{z} \\
\text { calculated for } \mathrm{C}_{25} \mathrm{H}_{26} \mathrm{~N}_{5} \mathrm{O}_{2}[\mathrm{M}+\mathrm{H}]^{+} 428.2081, \text { found } 428.2092 .\end{array}$ \\
\hline
\end{tabular}




\begin{tabular}{|c|c|}
\hline $23 b$ & 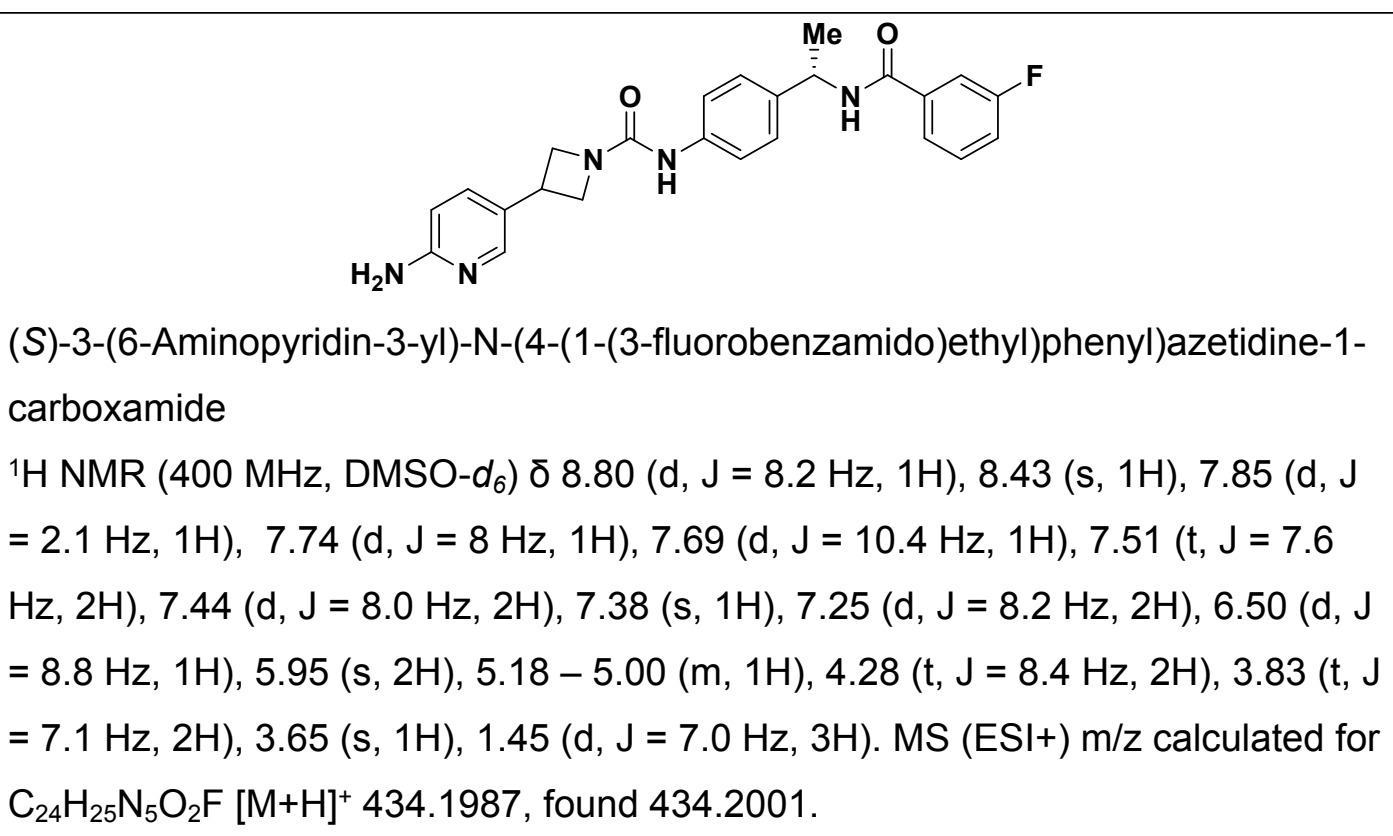 \\
\hline $23 c$ & 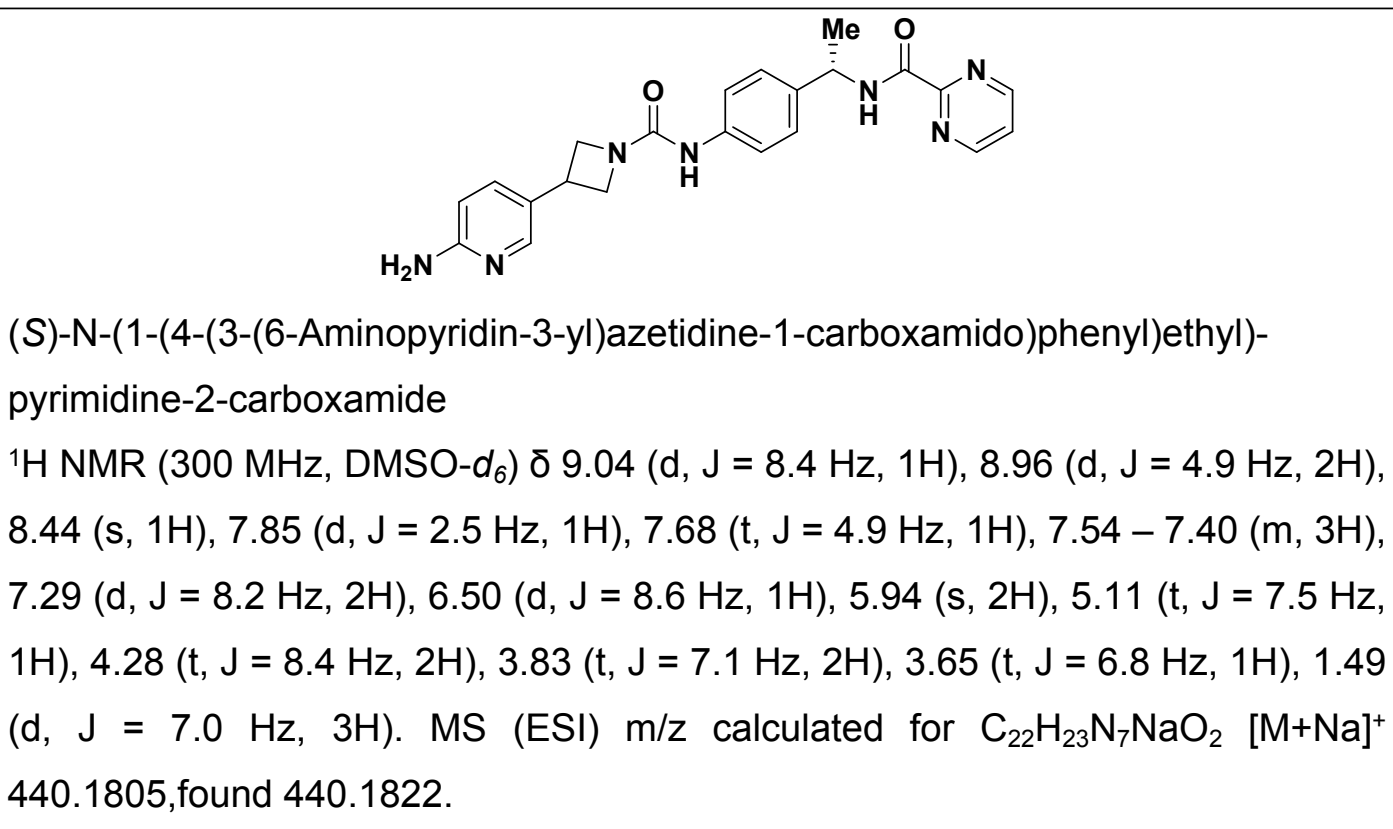 \\
\hline $23 d$ & $\begin{array}{l}\text { (S)-3-(6-Aminopyridin-3-yl)- } \mathrm{N} \text {-(4-(1-(tetrahydro-2H-pyran-4-carboxamido)- } \\
\text { ethyl)phenyl)azetidine-1-carboxamide }\end{array}$ \\
\hline
\end{tabular}




\begin{tabular}{|c|c|}
\hline & $\begin{array}{l}{ }^{1} \mathrm{H} \text { NMR }\left(400 \mathrm{MHz}, \mathrm{DMSO}-\mathrm{d}_{6}\right) \delta 8.38(\mathrm{~s}, 1 \mathrm{H}), 8.08(\mathrm{~d}, \mathrm{~J}=8.2 \mathrm{~Hz}, 1 \mathrm{H}), 7.84(\mathrm{~d}, \mathrm{~J}= \\
2.4 \mathrm{~Hz}, 1 \mathrm{H}), 7.47-7.40(\mathrm{~m}, 3 \mathrm{H}), 7.17-7.13(\mathrm{~m}, 2 \mathrm{H}), 6.47(\mathrm{~d}, \mathrm{~J}=8.5 \mathrm{~Hz}, 1 \mathrm{H}), 5.81 \\
(\mathrm{~s}, 2 \mathrm{H}), 4.85-4.81(\mathrm{~m}, 1 \mathrm{H}), 4.28(\mathrm{t}, \mathrm{J}=8.3 \mathrm{~Hz}, 2 \mathrm{H}), 3.86-3.81(\mathrm{~m}, 4 \mathrm{H}), 3.65-3.62 \\
(\mathrm{~m}, 1 \mathrm{H}), 3.30-3.25(\mathrm{~m}, 2 \mathrm{H}), 2.40-2.38(\mathrm{~m}, 1 \mathrm{H}), 1.58-1.50(\mathrm{~m}, 4 \mathrm{H}), 1.30(\mathrm{~d}, \mathrm{~J}=6.9 \\
\mathrm{Hz}, 3 \mathrm{H}) . \mathrm{MS}(\mathrm{ESI}+) \mathrm{m} / \mathrm{z} \text { calculated for } \mathrm{C}_{23} \mathrm{H}_{30} \mathrm{~N}_{5} \mathrm{O}_{3}[\mathrm{M}+\mathrm{H}]^{+} 424.2343 \text {, found } \\
\text { 424.2356. }\end{array}$ \\
\hline $23 e$ & $\begin{array}{l}\text { (S)-N-((S)-1-(4-(3-(6-Aminopyridin-3-yl)azetidine-1-carboxamido)phenyl)ethyl)-1- } \\
\text { methylpyrrolidine-2-carboxamide } \\
{ }^{1} \mathrm{H} \mathrm{NMR}\left(400 \mathrm{MHz}, \mathrm{DMSO}-\mathrm{d}_{6}\right) \delta 8.39(\mathrm{~s}, 1 \mathrm{H}), 7.91-7.78(\mathrm{~m}, 2 \mathrm{H}), 7.54-7.22(\mathrm{~m} \text {, } \\
3 \mathrm{H}), 7.26-7.14(\mathrm{~m}, 2 \mathrm{H}), 6.47(\mathrm{~d}, \mathrm{~J}=8.4 \mathrm{~Hz}, 1 \mathrm{H}), 5.80(\mathrm{~s}, 2 \mathrm{H}), 4.86(\mathrm{q}, \mathrm{J}=7.2 \mathrm{~Hz} \text {, } \\
1 \mathrm{H}), 4.28(\mathrm{t}, \mathrm{J}=8.3 \mathrm{~Hz}, 2 \mathrm{H}), 3.83(\mathrm{dd}, \mathrm{J}=7.7,6.5 \mathrm{~Hz}, 2 \mathrm{H}), 3.64(\mathrm{t}, \mathrm{J}=7.6 \mathrm{~Hz}, 1 \mathrm{H}), \\
\text { 3.02 (dd, J=8.4, 4.6 Hz, 1H), } 2.69(\mathrm{dd}, \mathrm{J}=9.2,5.8 \mathrm{~Hz}, 1 \mathrm{H}), 2.23(\mathrm{~s}, 4 \mathrm{H}), 2.10- \\
1.96(\mathrm{~m}, 1 \mathrm{H}), 1.70(\mathrm{~m}, 3 \mathrm{H}), 1.35(\mathrm{~d}, \mathrm{~J}=6.9 \mathrm{~Hz}, 3 \mathrm{H}) . \mathrm{MS}(\mathrm{ESI}+) \mathrm{m} / \mathrm{z} \mathrm{calculated} \\
\mathrm{C}_{23} \mathrm{H}_{31} \mathrm{~N}_{6} \mathrm{O}_{2}[\mathrm{M}+\mathrm{H}]^{+} 423.2503, \text { found } 423.2513 .\end{array}$ \\
\hline $23 f$ & 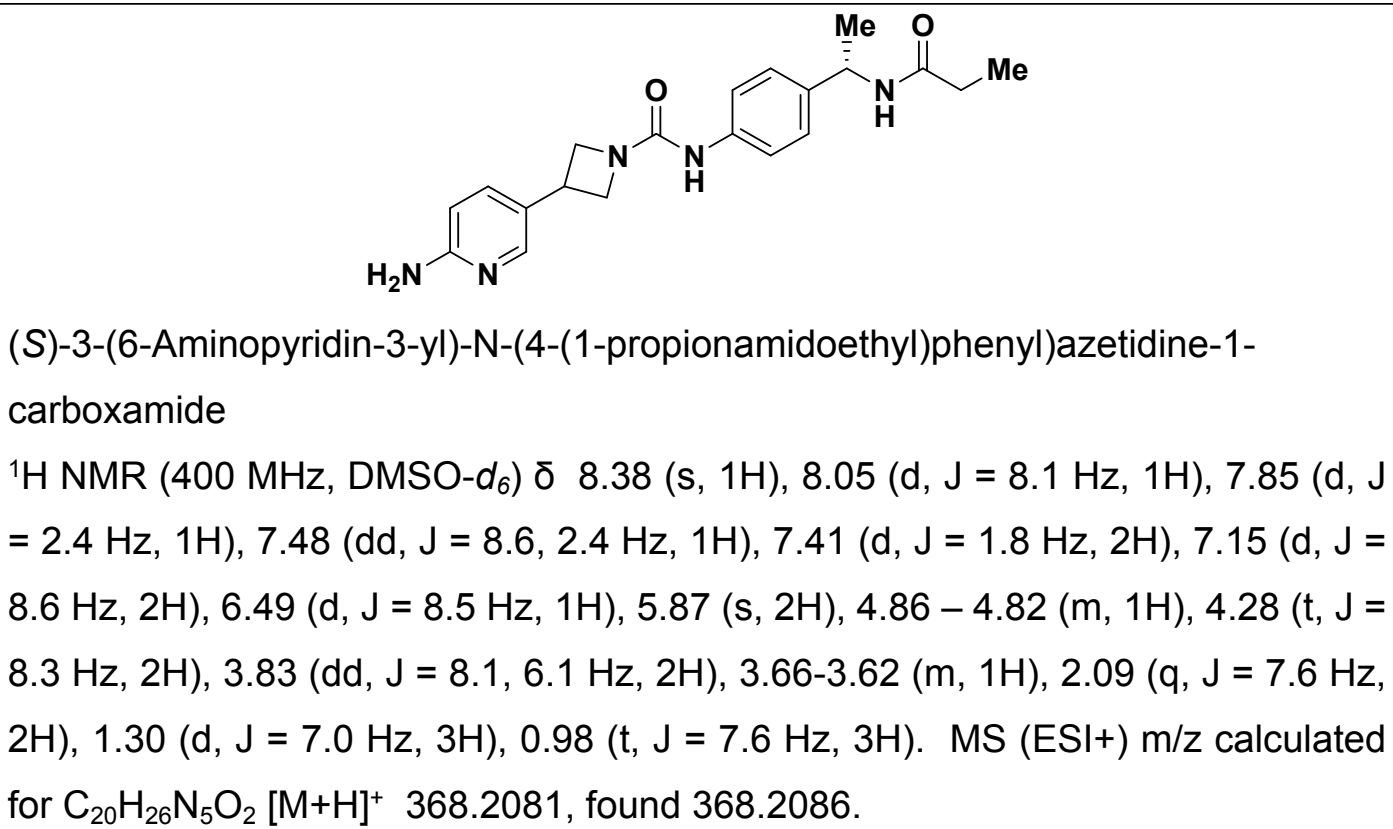 \\
\hline
\end{tabular}




\begin{tabular}{|c|c|}
\hline $24 a$ & 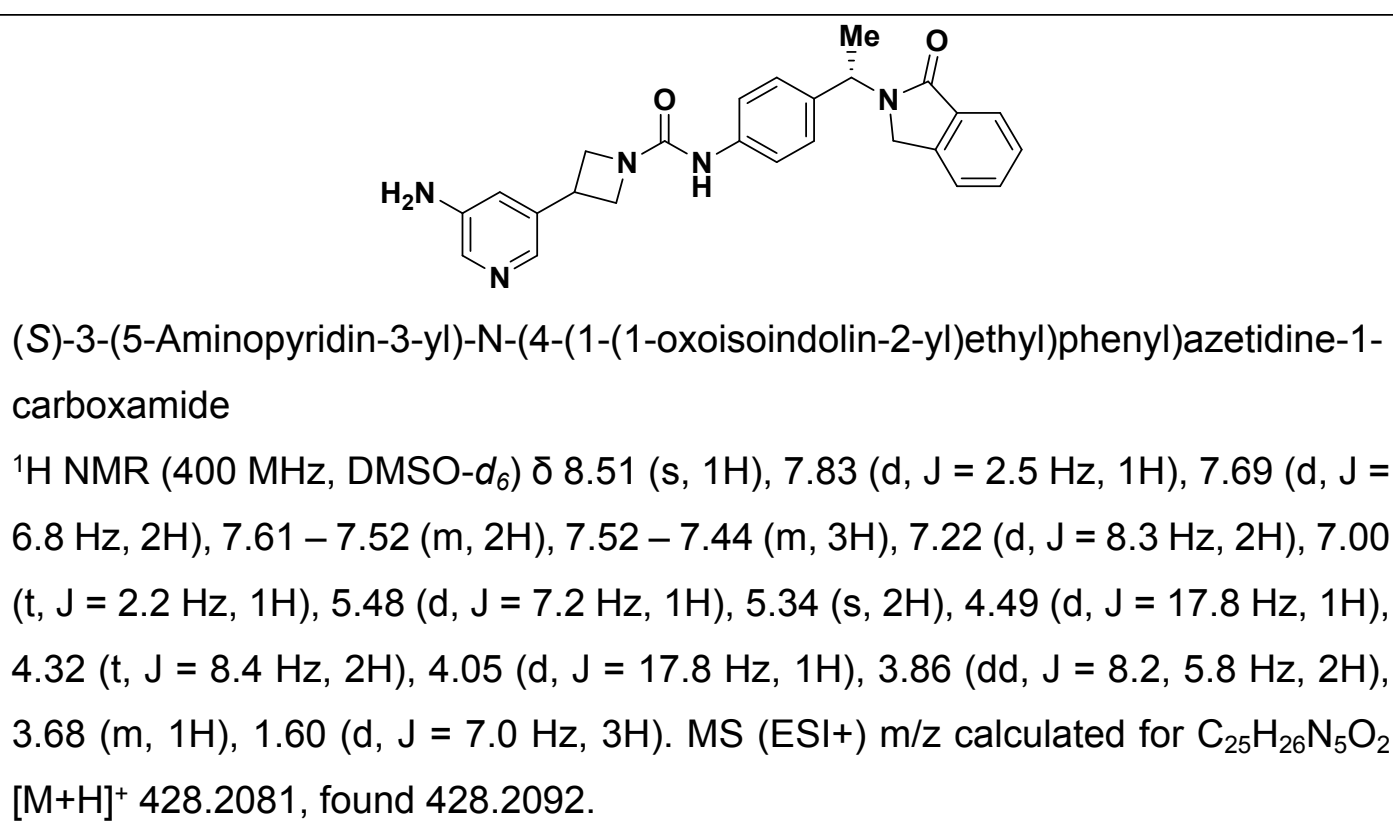 \\
\hline $24 b$ & $\begin{array}{l}\text { (S)-3-(5-Aminopyridin-3-yl)- } \mathrm{N} \text {-(4-(1-(3-fluorobenzamido)ethyl)phenyl)azetidine-1- } \\
\text { carboxamide } \\
{ }^{1} \mathrm{H} \mathrm{NMR}\left(400 \mathrm{MHz}, \mathrm{DMSO}-\mathrm{d}_{6}\right) \delta 8.78(\mathrm{~d}, \mathrm{~J}=8.0 \mathrm{~Hz}, 1 \mathrm{H}), 8.46(\mathrm{~s}, 1 \mathrm{H}), 7.83(\mathrm{~d}, \mathrm{~J}= \\
2.5 \mathrm{~Hz}, 1 \mathrm{H}), 7.75-7.61(\mathrm{~m}, 3 \mathrm{H}), 7.54-7.49(\mathrm{~m}, 1 \mathrm{H}), 7.45-7.31(\mathrm{~m}, 3 \mathrm{H}), 7.25(\mathrm{~d} \text {, } \\
\mathrm{J}=8.4 \mathrm{~Hz}, 2 \mathrm{H}), 6.99(\mathrm{t}, \mathrm{J}=2.3 \mathrm{~Hz}, 1 \mathrm{H}), 5.32(\mathrm{~s}, 2 \mathrm{H}), 5.11(\mathrm{t}, \mathrm{J}=7.3 \mathrm{~Hz}, 1 \mathrm{H}), 4.32 \\
(\mathrm{t}, \mathrm{J}=8.4 \mathrm{~Hz}, 2 \mathrm{H}), 3.86(\mathrm{dd}, \mathrm{J}=8.1,5.8 \mathrm{~Hz}, 2 \mathrm{H}), 3.69(\mathrm{~d}, \mathrm{~J}=6.0 \mathrm{~Hz}, 1 \mathrm{H}), 1.46(\mathrm{~d} \text {, } \\
\mathrm{J}=7.0 \mathrm{~Hz}, 3 \mathrm{H}) . \mathrm{MS}(\mathrm{ESI}+) \mathrm{m} / \mathrm{z} \text { calculated for } \mathrm{C}_{24} \mathrm{H}_{25} \mathrm{FN}_{5} \mathrm{O}_{2}[\mathrm{M}+\mathrm{H}]^{+} 434.1987 \text {, } \\
\text { found } 434.2002 .\end{array}$ \\
\hline $24 c$ & $\begin{array}{l}\text { (S)-N-(1-(4-(3-(5-Aminopyridin-3-yl)azetidine-1-carboxamido)phenyl)- } \\
\text { ethyl)pyrimidine-2-carboxamide } \\
\text { 1H NMR }\left(400 \mathrm{MHz}, \mathrm{DMSO}-\mathrm{d}_{6}\right) \delta 9.00(\mathrm{~d}, \mathrm{~J}=8.4 \mathrm{~Hz}, 1 \mathrm{H}), 8.95(\mathrm{~d}, \mathrm{~J}=4.8 \mathrm{~Hz}, 2 \mathrm{H}) \text {, } \\
8.47(\mathrm{~s}, 1 \mathrm{H}), 7.83(\mathrm{~d}, \mathrm{~J}=2.5 \mathrm{~Hz}, 1 \mathrm{H}), 7.72-7.62(\mathrm{~m}, 2 \mathrm{H}), 7.49-7.39(\mathrm{~m}, 2 \mathrm{H}),\end{array}$ \\
\hline
\end{tabular}




\begin{tabular}{|c|c|}
\hline & $\begin{array}{l}7.29(\mathrm{~d}, \mathrm{~J}=8.5 \mathrm{~Hz}, 2 \mathrm{H}), 7.03(\mathrm{t}, \mathrm{J}=2.2 \mathrm{~Hz}, 1 \mathrm{H}), 5.39(\mathrm{~s}, 2 \mathrm{H}), 5.10(\mathrm{q}, \mathrm{J}=7.5 \mathrm{~Hz} \text {, } \\
1 \mathrm{H}), 4.33(\mathrm{t}, \mathrm{J}=8.4 \mathrm{~Hz}, 2 \mathrm{H}), 3.86(\mathrm{dd}, \mathrm{J}=8.2,5.8 \mathrm{~Hz}, 2 \mathrm{H}), 3.71-3.67(\mathrm{~m}, 1 \mathrm{H}), 1.49 \\
(\mathrm{~d}, \mathrm{~J}=7.0 \mathrm{~Hz}, 3 \mathrm{H}) . \mathrm{MS}(\mathrm{ESI}+) \mathrm{m} / \mathrm{z} \text { calculated for } \mathrm{C}_{22} \mathrm{H}_{24} \mathrm{~N}_{7} \mathrm{O}_{2}[\mathrm{M}+\mathrm{H}]^{+} 418.1991 \text {, } \\
\text { found } 418.1973 \text {. }\end{array}$ \\
\hline $24 d$ & $\begin{array}{l}\text { (S)-3-(5-Aminopyridin-3-yl)-N-(4-(1-(tetrahydro-2H-pyran-4-carboxamido)ethyl)- } \\
\text { phenyl)azetidine-1-carboxamide } \\
{ }^{1} \mathrm{H} \mathrm{NMR}\left(400 \mathrm{MHz}, \mathrm{DMSO}-\mathrm{d}_{6}\right) \delta 8.46(\mathrm{~s}, 1 \mathrm{H}), 8.11(\mathrm{~d}, \mathrm{~J}=8.2 \mathrm{~Hz}, 1 \mathrm{H}), 7.83(\mathrm{~s}, 1 \mathrm{H}) \text {, } \\
7.69(\mathrm{~s}, 1 \mathrm{H}), 7.42(\mathrm{~d}, \mathrm{~J}=8.2 \mathrm{~Hz}, 2 \mathrm{H}), 7.15(\mathrm{~d}, \mathrm{~J}=8.1 \mathrm{~Hz}, 2 \mathrm{H}), 7.05-6.90(\mathrm{~m}, 1 \mathrm{H}), \\
5.34(\mathrm{~s}, 2 \mathrm{H}), 4.84(\mathrm{p}, \mathrm{J}=7.2 \mathrm{~Hz}, 1 \mathrm{H}), 4.32(\mathrm{t}, \mathrm{J}=8.3 \mathrm{~Hz}, 2 \mathrm{H}), 3.87-3.84(\mathrm{~m}, 4 \mathrm{H}), \\
3.74-3.59(\mathrm{~m}, 1 \mathrm{H}), 3.32(\mathrm{~s}, 2 \mathrm{H}), 2.44-2.30(\mathrm{~m}, 1 \mathrm{H}), 1.57(\mathrm{~m}, 4 \mathrm{H}), 1.30(\mathrm{~d}, \mathrm{~J}= \\
6.9 \mathrm{~Hz}, 3 \mathrm{H}) . \mathrm{MS}(\mathrm{ESI}+) \mathrm{m} / \mathrm{z} \mathrm{calculated} \text { for } \mathrm{C}_{23} \mathrm{H}_{30} \mathrm{~N}_{5} \mathrm{O}_{3}[\mathrm{M}+\mathrm{H}]^{+} 424.2343, \text { found } \\
424.2356 \text {. }\end{array}$ \\
\hline $24 e$ & $\begin{array}{l}\text { (S)- } \mathrm{N}-((\mathrm{S})-1-(4-(3-(5-a m i n o p y r i d i n-3-y l) a z e t i d i n e-1-c a r b o x a m i d o) \text { phenyl)ethyl)-1- } \\
\text { methylpyrrolidine-2-carboxamide } \\
{ }^{1} \mathrm{H} \mathrm{NMR}\left(400 \mathrm{MHz}, \mathrm{DMSO}-\mathrm{d}_{6}\right) \delta 8.83(\mathrm{br} \mathrm{s}, 1 \mathrm{H}), 8.50(\mathrm{~s}, 1 \mathrm{H}), 7.83(\mathrm{~d}, \mathrm{~J}=2.5 \mathrm{~Hz} \text {, } \\
\text { 1H), } 7.70(\mathrm{~d}, \mathrm{~J}=1.9 \mathrm{~Hz}, 1 \mathrm{H}), 7.49-7.41(\mathrm{~m}, 2 \mathrm{H}), 7.24-7.12(\mathrm{~m}, 2 \mathrm{H}), 6.99(\mathrm{t}, \mathrm{J}= \\
\text { 2.2 Hz, } 1 \mathrm{H}), 5.37(\mathrm{br} \mathrm{s}, 2 \mathrm{H}), 4.91(\mathrm{p}, \mathrm{J}=7.1 \mathrm{~Hz}, 1 \mathrm{H}), 4.41-4.24(\mathrm{~m}, 2 \mathrm{H}), 4.00- \\
\text { 3.77 (m, 3H), } 3.75-3.62(\mathrm{~m}, 1 \mathrm{H}), 3.47(\mathrm{br} \mathrm{s}, 1 \mathrm{H}), 3.18-2.90(\mathrm{~m}, 1 \mathrm{H}), 2.75(\mathrm{br} \mathrm{s} \text {, } \\
\text { 3H), 2.46 - 2.35 (m, } 1 \mathrm{H}), 2.08-1.92(\mathrm{~m}, 1 \mathrm{H}), 1.89-1.66(\mathrm{~m}, 2 \mathrm{H}), 1.39(\mathrm{~d}, \mathrm{~J}=6.9 \\
\mathrm{Hz}, 3 \mathrm{H}) . \mathrm{MS}(\mathrm{ESI}+) \mathrm{m} / \mathrm{z} \text { calculated for } \mathrm{C}_{23} \mathrm{H}_{31} \mathrm{~N}_{6} \mathrm{O}_{2}[\mathrm{M}+\mathrm{H}]^{+} 423.2508: \text { found } \\
\text { 423.2518. }\end{array}$ \\
\hline
\end{tabular}




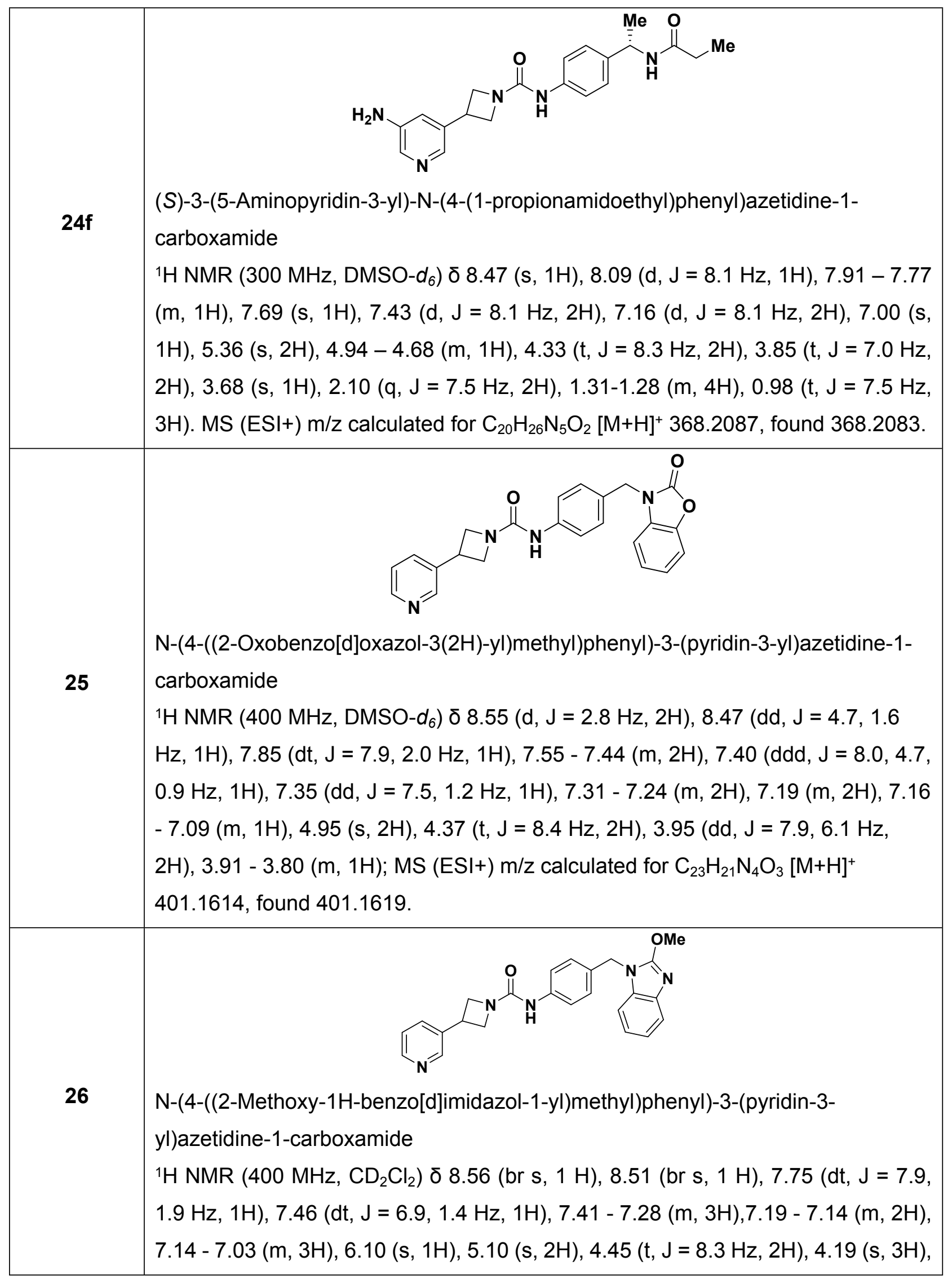




\begin{tabular}{|c|c|}
\hline & $\begin{array}{l}4.04(\mathrm{dd}, \mathrm{J}=7.9,5.9 \mathrm{~Hz}, 2 \mathrm{H}), 3.94-3.78(\mathrm{~m}, 1 \mathrm{H}) ; \mathrm{MS}(\mathrm{ESI}+) \mathrm{m} / \mathrm{zm} / \mathrm{z} \text { calculated } \\
\text { for } \mathrm{C}_{24} \mathrm{H}_{24} \mathrm{~N}_{5} \mathrm{O}_{2}[\mathrm{M}+\mathrm{H}]^{+} \text {414.1930, found 414.1929. }\end{array}$ \\
\hline 27 & $\begin{array}{l}\text { N-(4-((2-Ethoxy-1H-benzo[d]imidazol-1-yl)methyl)phenyl)-3-(pyridin-3- } \\
\text { yl)azetidine-1-carboxamide } \\
{ }^{1} \mathrm{H} N M R\left(400 \mathrm{MHz}, \mathrm{CD}_{2} \mathrm{Cl}_{2}\right) \delta 8.56(\mathrm{br} \mathrm{s}, 1 \mathrm{H}), 8.51(\mathrm{br} \mathrm{s}, 1 \mathrm{H}), 7.75(\mathrm{dt}, \mathrm{J}=7.9 \text {, } \\
1.9 \mathrm{~Hz}, 1 \mathrm{H}), 7.49-7.42(\mathrm{~m}, 1 \mathrm{H}), 7.41-7.30(\mathrm{~m}, 3 \mathrm{H}), 7.17(\mathrm{~d}, \mathrm{~J}=8.6 \mathrm{~Hz}, 2 \mathrm{H}), 7.14 \\
-7.02(\mathrm{~m}, 3 \mathrm{H}), 6.11(\mathrm{~s}, 1 \mathrm{H}), 5.11(\mathrm{~s}, 2 \mathrm{H}), 4.62(\mathrm{q}, \mathrm{J}=7.1 \mathrm{~Hz}, 2 \mathrm{H}), 4.45(\mathrm{t}, \mathrm{J}=8.3 \\
\mathrm{Hz}, 2 \mathrm{H}), 4.04(\mathrm{dd}, \mathrm{J}=7.9,5.8 \mathrm{~Hz}, 2 \mathrm{H}), 3.90-3.80(\mathrm{~m}, 1 \mathrm{H}), 1.47(\mathrm{t}, \mathrm{J}=7.1 \mathrm{~Hz}, 3 \mathrm{H}) \text {; } \\
\mathrm{MS}(\mathrm{ESI}+) \mathrm{m} / \mathrm{z} \text { calculated for } \mathrm{C}_{25} \mathrm{H}_{26} \mathrm{~N}_{5} \mathrm{O}_{2}[\mathrm{M}+\mathrm{H}]^{+} 428.2081 \text {; found } 428.2101 .\end{array}$ \\
\hline 28 & $\begin{array}{l}\mathrm{N}-(4-((2-B u t y l-4-0 x 0-1,3-d i a z a s p i r o[4.4] n o n-1-e n-3-y l) m e t h y l) p h e n y l)-3-(p y r i d i n-3- \\
\text { yl)azetidine-1-carboxamide } \\
{ }^{1} \mathrm{H} \mathrm{NMR}\left(400 \mathrm{MHz}, \mathrm{DMSO}-\mathrm{d}_{6}\right) \delta 8.59-8.52(\mathrm{~m}, 2 \mathrm{H}), 8.48(\mathrm{dd}, \mathrm{J}=4.7,1.6 \mathrm{~Hz}, 1 \mathrm{H}), \\
7.86(\mathrm{dt}, \mathrm{J}=7.9,2.0 \mathrm{~Hz}, 1 \mathrm{H}), 7.48(\mathrm{~d}, \mathrm{~J}=8.6 \mathrm{~Hz}, 2 \mathrm{H}), 7.41(\mathrm{dd}, \mathrm{J}=7.9,4.8 \mathrm{~Hz} \text {, } \\
1 \mathrm{H}), 7.04(\mathrm{~d}, \mathrm{~J}=8.6 \mathrm{~Hz}, 2 \mathrm{H}), 4.59(\mathrm{~s}, 2 \mathrm{H}), 4.37(\mathrm{t}, \mathrm{J}=8.3 \mathrm{~Hz}, 2 \mathrm{H}), 3.99-3.92(\mathrm{~m} \text {, } \\
2 \mathrm{H}), 3.92-3.81(\mathrm{~m}, 1 \mathrm{H}), 2.34-2.24(\mathrm{~m}, 2 \mathrm{H}), 1.85(\mathrm{~d}, \mathrm{~J}=8.5 \mathrm{~Hz}, 6 \mathrm{H}), 1.68-1.61 \\
(\mathrm{~m}, 2 \mathrm{H}), 1.47(\mathrm{p}, \mathrm{J}=7.5 \mathrm{~Hz}, 2 \mathrm{H}), 1.30-1.21(\mathrm{~m}, 2 \mathrm{H}), 0.80(\mathrm{t}, \mathrm{J}=7.3 \mathrm{~Hz}, 3 \mathrm{H}) ; \mathrm{MS} \\
(\mathrm{ESI}+) \mathrm{m} / \mathrm{z} \text { calculated for } \mathrm{C}_{27} \mathrm{H}_{34} \mathrm{~N}_{5} \mathrm{O}_{2}[\mathrm{M}+\mathrm{H}]^{+} 460.2713, \text { found } 460.2717 .\end{array}$ \\
\hline
\end{tabular}

Compound

SI-9:

N-((S)-1-(4-((1S,2S)-2-(pyridin-3-yl)cyclopropane-1-

carboxamido)phenyl)ethyl)benzamide<smiles>C[C@H](NC(=O)c1ccccc1)c1ccc(NC(=O)C2C[C@H]2c2cccnc2)cc1</smiles> 
See Palacios D.S. et al Bioorg Med Chem Lett 2018, 28, 365-370 for the synthesis of this compound.

\section{Comparison of potency and ADME properties of SI-9 and 27}

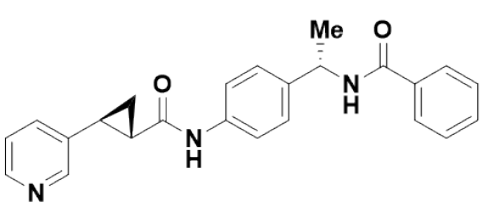

SI-9

Potency:

A2780 IC $50: 1 \mathrm{nM}$

CORL23 IC $50: 8 \mathrm{nM}$

ADME:

Sol $_{6.8}:<0.004 \mathrm{mM}$

MDCK $P_{\text {app }} A B: 16.6$

Mouse microsome $\mathrm{Cl}_{\text {int }}$ :

$148 \mu \mathrm{L} / \mathrm{min}^{*} \mathrm{mg}$

CYP3A4: $17.1 \mu \mathrm{M}$

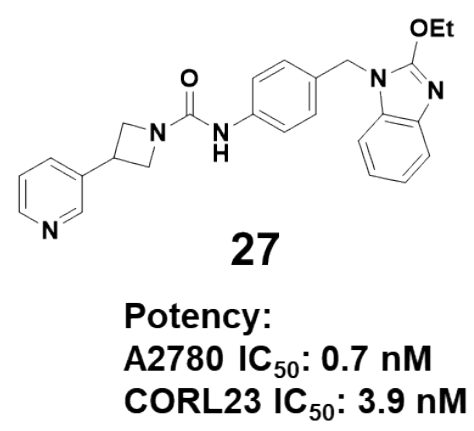

ADME:

Sol $_{6.8}: 0.056 \mathrm{mM}$

MDCK $P_{\text {app }} A B: 18.6$

Mouse microsome $\mathrm{Cl}_{\text {int }}$ :

$110 \mu \mathrm{L} / \mathrm{min}^{*} \mathrm{mg}$

CYP3A4: $0.75 \mu \mathrm{M}$

\section{Pharmacology}

\section{Cell Culture}

A2780 cells were maintained in triple flasks with RPMI 1640 medium supplemented with 10\% Fetal Bovine Serum and 1\% Penicillin/Streptomycin. Upon reaching 90\% confluency, cells were split 1:10 for maintenance. Briefly: old media was poured from flasks into a waste container; cells were washed in $15 \mathrm{~mL}$ PBS; monolayer was bathed in $15 \mathrm{~mL}$ TrypLE which was removed prior to incubation for 5 minutes at $37^{\circ} \mathrm{C}$. Detached cells were then resupended in $30 \mathrm{~mL}$ maintenance media and vortexed to disassociate; $3 \mathrm{~mL}$ of this solution was then added to a new triple flask with $150 \mathrm{~mL}$ of fresh maintenance media. CORL23 cells were treated similarly and were cultured as adherent monolayers and maintained in RPMI-1640 complete medium supplemented with heat-inactivated $5 \%$ fetal bovine serum, $1 \%$ penicillin-streptomycin solution, and $1 \mathrm{mM}$ glutamine

\section{General Cellular Assay Protocol}

On day 0, A2780 or CORL23 cells were harvested and counted on a ViCell. Cells were then resuspended in maintenance media at a concentration of 125,000 cells $/ \mathrm{mL}$ for plating. Plating was conducted on a GNF bottle-valve dispenser using straight tips, 4uL/well (500 cells/well). Plates were incubated overnight in a humidified chamber, $37^{\circ} \mathrm{C}, 5 \% \mathrm{CO}_{2}$. Compound plates were retrieved from Compound Management, pre-arrayed in LabCyte Echo 1536-well 
plates with columns 45-48 empty for controls. Compounds were delivered in 16-point, 3.16-fold dilution series starting at $2 \mathrm{mM}$ (all concentrations in DMSO).

On day 1, a control plate was prepared (4uL/well) in a LabCyte Echo 1536-well plate: column 45 = 10mM MG132, column $46=$ DMSO, column $47=200 \mathrm{uM} \mathrm{FK-866,} \mathrm{column} 48=200 \mathrm{uM}$ postive control compound. Compounds and controls were transferred via the Echo acoustic dispenser, 30nL/well, in 6 cross-plate replicates. After returning to the incubator for one hour, 3 plate replicates received $2 \mathrm{uL}$ of a $300 \mathrm{uM}$ solution of nicotinamide mononucleotide (final concentration 100uM) solvated in RPMI, while the remaining 3 replicates received 2uL of RPMI; both additions by straight single-tip dispense on GNF bottle valve dispenser. Plates were then returned to the humidified incubator and maintained at $37^{\circ} \mathrm{C}, 5 \% \mathrm{CO}_{2}$ for 72 hours.

On day 4, plates were brought to an open hotel position for a 15 minute equilibration to room temperature. CellTiterGlo was then added, 4uL/well, using a GNF bottle-valve dispenser (straight tips). Following a 15 minute incubation at room temperature, plates were read for luminescence on a Viewlux (1 second exposure, no binning).

Curves were analyzed in Helios, with normalization to both active (MG132) and neutral (DMSO) controls (NC1 normalization, such that neutral control $=0$ and active control $=100$ ). Equation for normalization shown below. For the NMN rescue experiments, the protocol is the same, except the cells were cultured in the presence of 100 uM NMN.

$$
-100 \frac{x-N C}{A C-N C}
$$

\section{Biochemical experiments}

The assay was performed in a 384-well format using the BioRaptor liquid dispenser for all reagent transfers. The NAMPT biochemical reaction consisted of $\mathrm{N}^{15}$-labeled Nicotinamide (NAM), Adenosine-5'-triphosphate (ATP), 5-Phospho-D-ribose 1-diphosphate (PRPP), and full-length human recombinant NAMPT enzyme. The reaction buffer consisted of $20 \mathrm{mM}$ HEPES, $\mathrm{pH} 8.0$, $20 \mathrm{mM} \mathrm{KCl}, 0.005 \mathrm{mM}$ MNG-3, 300 uM glycerol, and $1 \mathrm{mM}$ DDT. An 1.5x enzyme solution of NAMPT was prepared in reaction buffer at a concentration of $20 \mathrm{nM}$ (final concentration). A 3x substrate solution was prepared in reaction buffer with 1.5 uM NAM-amide ${ }^{15} \mathrm{~N}, 2.5 \mathrm{mM}$ ATP, and 3 uM PRPP (final concentrations). For compound treatments, 200nL of compound was added to enzyme preparation (10uL), pre-incubated for 15 minutes prior to addition of substrate (5uL), and incubated for 90 minutes at room temperature. The reaction was then quenched with $15 \mathrm{uL}$ of 
the quench solution, $250 \mathrm{nM}$ Nicotinamide Mononucleotide (NMN) in $1 \%$ formic acid. Plates were either analyzed that day of preparation or frozen at $-80^{\circ} \mathrm{C}$ until analysis.

For LCMS analysis, 10uL of each sample was injected onto an LX4 Quantum Vantage quadrupole mass spectrometer (ThermoFisher) and resolved on a hypercarb guard column $(20 \times 2.1 \mathrm{~mm}, 5$ um, ThermoFisher Javelin). The mobile phase consisted of $0.1 \%$ Formic Acid (Buffer A) and acetonitrile containing $0.1 \%$ formic acid $(B)$. The gradient consisted of $0 \% \mathrm{~B}$ for $30 \mathrm{~s}$, step to 35 $\%$ B for 15 s, step to $50 \%$ B for 15 s, step to $95 \%$ B for 5 s, hold for 15 s, and return to $0 \%$ B for up to a 2-minute final gradient run and instrument analysis was performed in positive ion mode. Ultrapure nitrogen gas was used for nebulization and argon was used as the collision gas. The optimized spray voltage and temperature were set to $3500 \mathrm{~V}$ and $400{ }^{\circ} \mathrm{C}$. The Quantum Vantage quadrupole mass spectrometer was operated under multiple reaction-monitoring mode with electrospray ionization. The precursor-to-product ion transitions $\mathrm{m} / \mathrm{z} 335 \rightarrow \mathrm{m} / \mathrm{z} 97$ and $\mathrm{m} / \mathrm{z}$ $335 \rightarrow \mathrm{m} / \mathrm{z} 123$ for NMN-amide15N and $\mathrm{m} / \mathrm{z} 336 \rightarrow \mathrm{m} / \mathrm{z} 97$ and $\mathrm{m} / \mathrm{z} 336 \rightarrow \mathrm{m} / \mathrm{z} 124$ for NMN were used for qualification. The collision energies were $24,13,13$, and 13 respectively. Areas under the curves were calculated for the enzymatic product $\left(\mathrm{NMN}-\mathrm{N}^{15}\right)$ as well as the internal standard (unlabeled NMN) for each injection and ratios were calculated of Area NMN-N15/Area NMN for each sample. Ratios for each unknown were then used to determine \% inhibition compared to the control samples on each plate which consisted of the neutral control (enzymatic reaction with DMSO only) and the active control (pre-quenched reaction). $I_{50}$ calculations were done using the absolute $\mathrm{IC}_{50}$ calculation, which gives concentration of compound that produces $50 \%$ inhibition.

\section{XRay Crystallography}

\section{NAMPT expression and purification}

A NAMPT construct featuring a C-terminal 8xHis tag was generated by inserting the human NAMPT gene (uniprot entry P43490) between the Ndel and Xhol restriction sites of pET41b. NAMPT was expressed and purified as described in http://www.pnas.org/content/106/33/13748.full.pdf?with-ds=yes except for a modified size exclusion buffer containing $20 \mathrm{mM}$ Tris $\mathrm{pH}$ 7.9, $150 \mathrm{mM} \mathrm{NaCl}$ and $2 \mathrm{mM}$ DTT.

\section{NAMPT co-crystallization and structure determination}

Full-length NAMPT protein in $20 \mathrm{mM}$ Tris pH 7.9, $150 \mathrm{mM} \mathrm{NaCl}, 2 \mathrm{mM}$ DTT was supplemented with NVP-LTM976 to a final concentration of $2 \mathrm{mM}$, concentrated to $6 \mathrm{mg} / \mathrm{mL}$ and crystallized in sitting drops at $293 \mathrm{~K}$. Crystals grew in conditions containing 100 mM Sodium Phosphate, 200 
$\mathrm{mM} \mathrm{NaCl}, 30-36 \%$ PEG 3350. For cryo-protection, crystals were incubated in reservoir solution supplemented with $8 \%$ glycerol ( $v / v)$ before harvesting and freezing in liquid $\mathrm{N}_{2}$.

X-ray data was collected at the Advanced Photon Source beamline 17-ID on a Pilatus 6M detector at a wavelength of $1 \AA$. Reflections were indexed, integrated, and scaled using autoPROC (Vonrhein et al., 2011 https://www.ncbi.nlm.nih.gov/pmc/articles/PMC3069744/). The structure was determined by molecular replacement using the program PHASER (McCoy et al., 2007 http://scripts.iucr.org/cgi-bin/paper?he5368) and the apo NAMPT structure (pdb code 2E5B) as a search model. Fo-Fc difference electron density at the active site indicated the presence of ligands. NVP-LTM976 was placed into electron densities in coot (Emsley et al., 2010 https://www.ncbi.nlm.nih.gov/pubmed/20383002) followed by iterative rounds of model building and refinement in BUSTER (Bricogne G., Blanc E., Brandl M., Flensburg C., Keller P., Paciorek W., Roversi P, Sharff A., Smart O.S., Vonrhein C., Womack T.O. (2016). BUSTER version 2.11.2. Cambridge, United Kingdom: Global Phasing Ltd.). The structure was refined to an R-factor of 0.159 (Rfree=0.209) with good geometry and without residues in the disallowed regions of the Ramachandran plot. Data collection and refinement statistics are shown in Table 1.

\section{Table 1}

\section{Compound 3}

(PDB code 6PEB)

\begin{tabular}{ll}
\hline Data collection & \\
Beamline & APS ID17 \\
Space group & P2 ${ }_{1} 2_{1} 2_{1}$ \\
Cell dimensions & \\
a, b, c ( $(\AA)$ & $89.74,96.16,246.84$ \\
$\alpha, \beta, \gamma\left({ }^{\circ}\right)$ & $90.0,90.0,90.0$ \\
& \\
Resolution $(\AA)$ & $2.46(2.59)^{\mathrm{a}}$ \\
$\mathrm{R}_{\text {sym }}$ & $0.047(0.47)$ \\
I/ $\sigma(I)$ & $13.3(3.3)$ \\
Completeness (\%) & $99.9(99.9)$ \\
\hline
\end{tabular}




\begin{tabular}{ll}
\hline Redundancy & $6.5(6.6)$ \\
Refinement & \\
Resolution (Å) & 2.46 \\
No. reflections & 78,711 \\
$R_{\text {work }} / \mathrm{R}_{\text {free }}$ & $0.159 / 0.209$ \\
No. atoms & \\
Protein & 15,019 \\
Ligand/ion & 153 \\
Water & 706 \\
Mean B value & 72.66 \\
R.m.s. deviations & \\
Bond lengths (Å) & 0.010 \\
Bond angles ( $\left.{ }^{\circ}\right)$ & 1.14
\end{tabular}

a Values in parentheses are for highest-resolution shell.

\section{Experimental Measurement of Permeation with MDCK-LE Cell Monolayer Assay}

Cell Culture: MDCK-LE cells are a low efflux (LE) cell line developed internally at Novartis using methodology similar to that previously reported. ${ }^{1}$

MDCK-LE cells were cultured at $37{ }^{\circ} \mathrm{C}$ under a 5\% CO2 atmosphere, at 95\% relative humidity in DMEM containing 10\% FBS, penicillin-streptomycin $(100 \mu \mathrm{g} / \mathrm{mL})$, and $2 \mathrm{mM}$ Ala-Gln. Cells were passaged weekly into an Omnitray (Nunc, Thermo Fisher Scientific, Rochester, NY) at a density of approximately $5750 \mathrm{cell} / \mathrm{cm}^{2}$ for continuous culture. For assay purposes, cells were seeded at a density of approximately 265,000 cells $/ \mathrm{cm}^{2}$ of a 96 -well Transwell plate (Corning Life Sciences, Acton, MA) and cultured in the same media noted above for a period of 4 days.

Assay: The determination of the apparent permeability (Papp) was performed in the $A \rightarrow B$ direction where each compound was assayed in triplicate in a pool of three compounds, similar to that previously reported. ${ }^{1}$ The zwitterion bestatin, a poorly permeably compound, was used as 
marker of monolayer integrity and was included as a fourth compound in the cassette of three compounds. To initiate the assay, media was aspirated, and the cells and basal chambers were washed three times with Hank's Balanced Salt Solution (HBSS) containing $10 \mathrm{mM} \mathrm{HEPES} \mathrm{(pH}$ 7.4). Compound test solutions were prepared in triplicate in HBSS containing $10 \mathrm{mM} \mathrm{HEPES} \mathrm{(pH}$ 7.4 ) and $0.02 \%$ bovine serum albumin (BSA) to a final concentration of $10 \mu \mathrm{M}$ and centrifuged for $2 \mathrm{~min}$ at $4000 \mathrm{~g}$, then applied to the apical compartment (donor compartment) at time zero. Additionally, at time zero, a $37^{\circ} \mathrm{C}$ solution without test articles (HBSS + $10 \mathrm{mM} \mathrm{HEPES}(\mathrm{pH} 7.4)$ plus $0.02 \% \mathrm{BSA}$ ) was added to the receiver chamber (basal) of the Transwell plate. A time zero sample of the donor solution was also sampled for further analysis. The assay was conducted for a period of $120 \mathrm{~min}$ at $37{ }^{\circ} \mathrm{C}$ without shaking. At the time of assay termination, samples were taken from each donor compartment, and each acceptor compartment of the Transwell plate. To each of the 0 and 120 min samples was added an internal standard solution containing glyburide in water:acetonitrile, 50:50 (v:v). Concentration curves were prepared using a Labcyte Echo in the same matrix noted above. Samples and concentration curve samples were analyzed by mass spectroscopy. Mass Spectroscopy: Assay samples were loaded onto a RapidFire C4 cartridge by means of a RapidFire autosampler (Agilent, Santa Clara, CA). Chromatography was performed at a flow rate of $1.25 \mathrm{~mL} / \mathrm{min}$, loading with $0.1 \%$ formic acid in water and eluting in $0.1 \%$ formic acid in methanol. Mass spectroscopy was performed using an AB Sciex API5500 (Sciex, Frammingham, MA) equipped with a turbo ion spray source. The analyte concentration was calculated from the chromatographic peak area ratio of analyte to internal standard (glibenclamide, m/z $494 \rightarrow 169$ ), using Multiquant software V2.1(Sciex, Framingham, MA).

Calculations: $\mathrm{P}_{\mathrm{app}}$ values were determined as:

$$
P_{\text {app }}=\left(\frac{V_{A}}{A\left[D_{0}\right]}\right)\left(\frac{\left[A_{120}\right]}{t}\right)
$$

Percent recovery values were determined as:

$$
\% \text { recovery }=100\left(\frac{\left[A_{120}\right]+\left[D_{120}\right]}{D_{0}}\right)
$$

where $V_{A}$ is the volume of the acceptor $(\mathrm{mL}), A$ is the surface area of the membrane, $D_{0}$ is the donor solution concentration at $t=0, D_{120}$ is the donor solution concentration at $t=120, A_{120}$ is the acceptor solution concentration at $\mathrm{t}=120$, and $\mathrm{t}=$ time (seconds). The minimum significant ratio averaged 1.75 from independent experiments of 45 compounds used to validate the assay and the mean relative standard deviation was $19.8 \% . \mathrm{P}_{\text {app }}$ values were determined from triplicate 
wells using the mean acceptor and donor solution concentrations, where independent experiments were performed standard deviations are provided to distinguish from replicate samples within a single experiment.

\section{Solubility determination:}

The high-throughput (HT) equilibrium solubility assay was performed as described previously. ${ }^{2}$ Briefly, aliquots of compound as $10 \mathrm{mM}$ DMSO stock solution were plated and DMSO was removed under temperature and vacuum. $67 \mathrm{mM}$ phosphate buffer was added to the 96-well plate for a target concentration of $1 \mathrm{mM}$. The plate was sealed, incubated on a shaker at 1350 RPM and ambient temperature for 16-24 h, and then centrifuged for $20 \mathrm{~min}$ at 3750 RPM to pellet the precipitate. The supernatant was transferred to another plate and centrifuged a second time. Supernatant was diluted 200-fold with 50:50 acetonitrile/water and a 4-point calibration curve was constructed using 50:50 acetonitrile/water. Analysis of the supernatant concentration was performed based on the calibration curve, using an Agilent RapidFire-MS/MS mass spectrometer system.

\section{Mouse microsomal clearance experiment:}

A typical experiment is performed in 96-well format with shaking incubation at $37^{\circ} \mathrm{C}$. The in vitro metabolic clearance rate is derived from data collected at four time points (eg. 0, 5,15 and 30 minutes) in a reaction including cofactor(s) (NADPH and/or UDPGA). A 30 minutes negative control incubation (minus cofactor) is also performed to assess CYP-unrelated stability issues (eg, chemical instability, CYP-independent metabolism). In general, test compounds in $10 \mathrm{mM}$ DMSO are diluted $1: 1000$ into $0.6 \% \mathrm{MeCN}(v / v)$ in $\mathrm{H}_{2} \mathrm{O}$ to $10 \mu \mathrm{M}$. Immediately prior to the start of the experiment, $1.25 \mathrm{mg} / \mathrm{mL}$ of mouse microsomal protein is suspended in $50 \mathrm{mM}$ postassium phosphate ( $\mathrm{pH}$ 7.4). For evaluation of UGT-mediated metabolism, the suspension may be first pretreated by $5 \mathrm{~min}$ incubation on ice with alamethicin $(25 \mu \mathrm{g} / \mathrm{mg}$ of microsomal protein). Test compound $(35 \mu \mathrm{L})$ is then added to $140 \mu \mathrm{L}$ of the microsomal suspensions for $175 \mu \mathrm{L}$ enzymesubstrate mixture. This enzyme substrate mixture is preincubated for $15 \mathrm{~min}$ at $37^{\circ} \mathrm{C}$. The $30 \mathrm{~min}$ negative control incubation is processed by combining $25 \mu \mathrm{L}$ of enzyme substrate mixture with an equal volume of $50 \mathrm{mM}$ postassium phosphate $(\mathrm{pH} 7.4)$ containing $4 \mathrm{mM} \mathrm{MgCl}_{2}$. Following a 30 minute incubation at $37{ }^{\circ} \mathrm{C}$, the mix is quenched by adding $50 \mu \mathrm{L}$ of $\mathrm{MeCN}$ containing the MS internal standard ( $2 \mu \mathrm{M}$ alprenolol). The $\mathrm{T}=0 \mathrm{~min}$ time point is processed by combining $25 \mu \mathrm{L}$ of enzyme•substrate mixture directly with $50 \mu \mathrm{L}$ of MeCN containing the MS internal standard ( $2 \mu \mathrm{M}$ alprenolol). $25 \mu \mathrm{L}$ of the cofactor solution is added ( $2 \mathrm{mM}$ NADPH in 50 
$\mathrm{mM}$ potassium phosphate $\left(\mathrm{pH}\right.$ 7.4) plus $4 \mathrm{mM} \mathrm{MgCl}_{2}(\mathrm{pH} 7.4)$ to simulate the complete quenched reaction mixture.

The bulk reactions for the remaining time points are initiated by addition of $125 \mu \mathrm{L}$ of cofactor solution (2 mM NADPH in $50 \mathrm{mM}$ potassium phosphate $\left(\mathrm{pH} 7.4\right.$ ) plus $4 \mathrm{mM} \mathrm{MgCl}_{2}$ ) to the remaining $125 \mu \mathrm{L}$ of enzyme•substrate mixture. At specific reaction time points (eg. 5 , 15, 30 minutes), reaction aliquots $(50 \mu \mathrm{L})$ are removed and reactions are terminated by addition of acetonitrile $(50 \mu \mathrm{L})$ containing mass spectrometry internal standard $(2 \mu \mathrm{M}$ alprenolol). All the samples are centrifuged at $\sim 3400 \times g$ at $4{ }^{\circ} \mathrm{C}$ for $10 \mathrm{~min}$ and the supernatants are analyzed by LCMS/MS for quantitation of remaining test compound. The percentage of TA remaining, relative to 0 minutes, is used to estimate in vitro elimination-rate constant ( $k$ mic) which can be used to calculate in vitro metabolic clearance rates. The in vitro metabolic rate is then calculated using the following formulas:

$$
t_{1 / 2}=\frac{0.693}{-k_{\text {mic }}}
$$

and

$$
C L_{\text {int }}=\frac{0.693}{t_{1 / 2}} * \frac{V}{M}
$$

Where $\mathrm{V}$ is the incubation volume $(\mu \mathrm{L})$, and $\mathrm{M}$ is the microsomal protein content in the incubation (mg).

\section{Reversible CYP inhibition}

Breifly, $40 \mu \mathrm{L}$ of a $250 \mathrm{mM}$ solution of postassium phosphate $(\mathrm{pH} 7.4)$ and $12.5 \mathrm{mM} \mathrm{MgCl}_{2}$ containing $0.125 \mathrm{mg} / \mathrm{mL}$ CYP3A4 and $2.5 \mu \mathrm{M}$ midazolam is added to $10 \mu \mathrm{L}$ of compound (in 95:5 water:DMSO) serially diluted in the assay plate ( $50 \mu \mathrm{L}$ total). Reactions are initiated by adding an equal volume $(50 \mu \mathrm{L})$ of a $2 \mathrm{mM}$ NADPH solution to each well. Reactions are incubated at $37^{\circ} \mathrm{C}$ with shaking incubation. Termination of reactions by protein precipitation is achieved through addition of the quench solution $(185 \mu \mathrm{L})$ of acetonitrile containing 1-hydroxymidazolam as an internal standard for LC-MS/MS analysis. These plates are stored $4{ }^{\circ} \mathrm{C}$ for $40-130$ min prior to centrifugation. Following centrifugtation, $10 \mathrm{~min}$ at $2100 \mathrm{~g}\left(4^{\circ} \mathrm{C}\right)$, the resulting supernatants are transferred to a clean 384-well Ubottom, polypropylene plate, heat-sealed with foil and stored at $-80{ }^{\circ} \mathrm{C}$ to await analysis by LC-MS/MS.

\section{Plasma protein binding experiment}

The RED Teflon base plate (Thermo Scientific, Waltham, MA, USA) was soaked in $20 \%$ ethanol for $20 \mathrm{~min}$ and then rinsed twice in deionised water prior to use. RED Device inserts (MWCO 8000 , \#89809, Thermo Scientific) were pre-treated with $20 \%$ ethanol and rinsed in the same 
manner as for the base plate. Frozen plasma was thawed and centrifuged to remove the fibrin clot. Then the plasma was spiked with test compound solutions at $5 \mu \mathrm{M}$ and $1 \%$ DMSO concentrations. The spiked plasma $(300 \mu \mathrm{L})$ in triplicate was added to a plasma chamber of the insert and $500 \mu \mathrm{L}$ of $100 \mathrm{mM}$ phosphate buffer was added into the respective buffer chamber insert. The plate was sealed with a gas permeable adhesive seal (\#AB-0718, Thermo Scientific) and placed on a dynamic shaker (model V 2000, Kisker Biotech, Steinfurt, Germany) set at 750 $\mathrm{rpm}$. The shaker was placed inside an incubator set at $37^{\circ} \mathrm{C}, 5 \% \mathrm{CO}_{2}$ and without added humidity. After incubating for 4 hours, aliquots from the buffer and plasma chamber were removed and placed in a deep well plate. The buffer and plasma samples were supplemented with the opposite matrix ( $500 \mu \mathrm{L}$ of buffer was added to plasma samples and $300 \mu \mathrm{L}$ of control plasma was added to the buffer samples) to enable all samples to be matrix matched. Acetonitrile ( $150 \mu \mathrm{L})$ was added and mixed to precipitate proteins, and the deep well plate was centrifuged $(2800 \mathrm{~g})$. An aliquot of supernatant from each well was transferred to a clean 96-well plate and further diluted with water for analysis by LCMS. To enable calculation of \% plasma stability and \% recovery, aliquots of compound-spiked plasma (in triplicate) were directly transferred at time zero to a deep well plate and processed like the incubated samples. Percent bound was then calculated as below:

$$
\% f u=\frac{A U C \text { buffer }}{\text { post incubation }}
$$

Where the AUC is defined as the AUC of the test compound when analyzed by LCMS.

\section{In vivo experiments}

All animal studies were carried out in accordance with federal, state, local and institutional guidelines governing the use of laboratory animals in research. Female athymic nude mice (age 6-8 weeks) were purchased from Harlan Laboratories, Inc. For the exposure measurements, compound 27 was dissolved in 50\% (CREMOPHOR EL 20\%) 2\% HCL 1N, 2\% NaOH 1N, 20\% PEG 300 and three mice per dose group were dosed at 30, 5, 1, and $0.3 \mathrm{mg} / \mathrm{kg} .50 \mu \mathrm{L}$ of blood was collected (via tail transection) was collected at $0.5,1,4,7,16$ and 24 hours postdose. The samples and transferred to an Eppendorf microcentrifuge tube containing EDTA and the blood was centrifuged at $5000 \mathrm{rpm}$, and plasma was transferred to a Matrix 96-well plate, capped, and stored frozen $\left(-20{ }^{\circ} \mathrm{C}\right)$ for compound analysis. Samples were precipitated and diluted with acetonitrile-containing internal standard and prepared for LC/MS/MS. An aliquot (20 $\mu \mathrm{L})$ of each sample was injected into an API4000 LC/MS/MS system for analysis, and transitions of 428.20 amu (Q1) and 266.90 amu (Q3) were monitored. The data for each dose is shown below. The unbound mean was derived by multiplying the mean concentration by (100-96.2) which is the calculated plasma protein binding of compound 27 . 
$27, \mathrm{PO}, 30 \mathrm{mg} / \mathrm{kg}$

\begin{tabular}{|c|c|c|c|c|c|c|c|}
\hline $\begin{array}{c}\text { Time } \\
\text { (h) }\end{array}$ & $\begin{array}{c}\text { Subject } \\
\mathbf{1}\end{array}$ & $\begin{array}{c}\text { Subject } \\
\mathbf{2}\end{array}$ & $\begin{array}{c}\text { Subject } \\
\mathbf{3}\end{array}$ & $\begin{array}{c}\text { Mean } \\
\text { (nM) }\end{array}$ & SD & \%CV & $\begin{array}{c}\text { unbound } \\
\text { Mean } \\
\text { (nM) }\end{array}$ \\
\hline 0.5 & 256069.9 & 279030.1 & 305786.8 & $\mathbf{2 8 0 2 9 5 . 6}$ & 24882.61 & $9 \%$ & 10651.23 \\
\hline 1 & 198491.9 & 281218.3 & 250637.7 & $\mathbf{2 4 3 4 4 9 . 3}$ & 41829.07 & $17 \%$ & 9251.07 \\
\hline 4 & 149123.3 & 61674.06 & 86118.68 & $\mathbf{9 8 9 7 2 . 0 3}$ & 45119.29 & $46 \%$ & 3760.94 \\
\hline 7 & 46148.79 & 52513.43 & 23844.82 & $\mathbf{4 0 8 3 5 . 6 8}$ & 15054.71 & $37 \%$ & 1551.76 \\
\hline 16 & 326.64 & 187.81 & 145.31 & $\mathbf{2 1 9 . 9 2}$ & 94.83 & $43 \%$ & 8.36 \\
\hline 24 & 220.58 & 127.65 & 557.86 & $\mathbf{3 0 2 . 0 3}$ & 226.38 & $75 \%$ & 11.48 \\
\hline
\end{tabular}

$27, \mathrm{PO}, 10 \mathrm{mg} / \mathrm{kg}$ individual values

\begin{tabular}{|c|c|c|c|c|}
\hline Time (h) & Subject 3 & Subject 4 & Mean (nM) & \%CV \\
\hline 0.25 & 19892.4 & 15385.11 & $\mathbf{1 7 6 3 8 . 7 6}$ & $18 \%$ \\
\hline & & & & $1 \%$ \\
\hline 1 & 23962.31 & 27182.83 & $\mathbf{2 5 5 7 2 . 5 7}$ & $9 \%$ \\
\hline 2 & 8069.23 & 10067.71 & $\mathbf{9 0 6 8 . 4 7}$ & $16 \%$ \\
\hline 4 & 4018.17 & 5037.17 & $\mathbf{4 5 2 7 . 6 7}$ & $16 \%$ \\
\hline 7 & 2013.94 & 1394.2 & $\mathbf{1 7 0 4 . 0 7}$ & $26 \%$ \\
\hline
\end{tabular}

27, PO, $10 \mathrm{mg} / \mathrm{kg}$

\begin{tabular}{|c|c|c|c|c|}
\hline Subject & Subject 3 & Subject 4 & Mean & $\% \mathrm{CV}$ \\
\hline $\begin{array}{c}\text { AUC } \\
\text { (nM*Hours) }\end{array}$ & 59094 & 64875 & $\mathbf{6 1 9 8 4}$ & $7 \%$ \\
\hline $\begin{array}{c}\text { AUC Extrap } \\
\text { (nM*Hours) }\end{array}$ & 66448 & 68378 & $\mathbf{6 7 4 1 3}$ & $2 \%$ \\
\hline Cmax (nM) & 29277 & 28947 & $\mathbf{2 9 1 1 2}$ & $1 \%$ \\
\hline $\begin{array}{c}\text { Tmax } \\
\text { (Hours) }\end{array}$ & 0.5 & 0.5 & $\mathbf{0 . 5}$ & $0 \%$ \\
\hline T 1/2 (Hours) & & & $\mathbf{2 . 1}$ & \\
\hline T Last () & (0-7 Hours) & (0-7 Hours) & $\mathbf{7}$ & \\
\hline
\end{tabular}




\begin{tabular}{|c|c|c|c|c|c|c|c|}
\hline $\begin{array}{c}\text { Time } \\
\text { (h) }\end{array}$ & $\begin{array}{c}\text { Subject } \\
\mathbf{4}\end{array}$ & $\begin{array}{c}\text { Subject } \\
\mathbf{5}\end{array}$ & $\begin{array}{c}\text { Subject } \\
\mathbf{6}\end{array}$ & $\begin{array}{c}\text { Mean } \\
\text { (nM) }\end{array}$ & SD & \%cV & $\begin{array}{c}\text { unbound } \\
\text { Mean } \\
\text { (nM) }\end{array}$ \\
\hline 0.5 & 66412.27 & 48666.23 & 46148.79 & $\mathbf{5 3 7 4 2 . 4 3}$ & 11044.37 & $21 \%$ & 2042.21 \\
\hline 1 & 40650 & 44138.1 & 31752.53 & $\mathbf{3 8 8 4 6 . 8 8}$ & 6386.63 & $16 \%$ & 1476.18 \\
\hline 4 & 17825.29 & 13875.63 & 12594.79 & $\mathbf{1 4 7 6 5 . 2 4}$ & 2726.37 & $18 \%$ & 561.08 \\
\hline 7 & 5291.16 & 3212.45 & 5592.49 & $\mathbf{4 6 9 8 . 7}$ & 1295.92 & $28 \%$ & 178.55 \\
\hline 16 & 103.65 & 80.51 & 93 & $\mathbf{9 2 . 3 9}$ & 11.58 & $13 \%$ & 3.51 \\
\hline 24 & 65.5 & 80 & 55.25 & $\mathbf{6 6 . 9 2}$ & 12.43 & $19 \%$ & 2.54 \\
\hline
\end{tabular}

\begin{tabular}{|c|c|c|c|c|c|c|c|}
\hline \multicolumn{8}{|c|}{$27, \mathrm{PO}, 1 \mathrm{mg} / \mathrm{kg}$} \\
\hline $\begin{array}{c}\text { Time } \\
\text { (h) }\end{array}$ & $\begin{array}{c}\text { Subject } \\
7 \\
\end{array}$ & $\begin{array}{c}\text { Subject } \\
8 \\
\end{array}$ & $\begin{array}{c}\text { Subject } \\
9 \\
\end{array}$ & $\begin{array}{c}\text { Mean } \\
(\mathrm{nM})\end{array}$ & SD & $\% \mathrm{CV}$ & $\begin{array}{c}\text { unbound } \\
\text { Mean } \\
\text { (nM) }\end{array}$ \\
\hline 0.5 & 9988.64 & 5348.59 & 9914.89 & 8417.37 & 2657.9 & $32 \%$ & 319.86 \\
\hline 1 & 6038.68 & 4948.5 & 4852.87 & 5280.02 & 658.76 & $12 \%$ & 200.64 \\
\hline 4 & 1283 & 1675.88 & 1188.01 & 1382.3 & 258.65 & $19 \%$ & 52.53 \\
\hline 7 & 879.01 & 653.44 & 500.95 & 677.8 & 190.2 & $28 \%$ & 25.76 \\
\hline 16 & 67.02 & 47.63 & 54.39 & 56.34 & 9.84 & $17 \%$ & 2.14 \\
\hline 24 & 49.03 & 59.91 & 52.82 & 53.92 & 5.52 & $10 \%$ & 2.05 \\
\hline
\end{tabular}

\begin{tabular}{|c|c|c|c|c|c|c|c|}
\hline \multicolumn{8}{|c|}{$27, P O, 0.30 \mathrm{mg} / \mathrm{kg}$} \\
\hline $\begin{array}{c}\text { Time } \\
\text { (h) }\end{array}$ & $\begin{array}{c}\text { Subject } \\
10\end{array}$ & $\begin{array}{c}\text { Subject } \\
11\end{array}$ & $\begin{array}{c}\text { Subject } \\
12\end{array}$ & $\begin{array}{c}\text { Mean } \\
(\mathrm{nM})\end{array}$ & SD & $\% \mathrm{CV}$ & $\begin{array}{l}\text { unbound } \\
\text { Mean } \\
\text { (nM) }\end{array}$ \\
\hline 0.5 & 2057 & 1614.01 & 2184.86 & 1951.96 & 299.57 & $15 \%$ & 74.17 \\
\hline 1 & 760.06 & 402.03 & 497.12 & 553.07 & 185.46 & $34 \%$ & 21.02 \\
\hline 4 & 221.8 & 255.79 & 300.67 & 259.42 & 39.56 & $15 \%$ & 9.86 \\
\hline 7 & 207.9 & 206.31 & 332.11 & 248.78 & 72.18 & $29 \%$ & 9.45 \\
\hline 16 & 52.28 & 46.85 & 59.09 & 52.74 & 6.13 & $12 \%$ & 2.00 \\
\hline 24 & 39.32 & 20.49 & 37.36 & 32.39 & 10.35 & $32 \%$ & 1.23 \\
\hline
\end{tabular}

For the tolerability experiment, animals were randomized by body weight and assigned to treatment groups (4 mice per group) for the duration of the study. Compound 27 was formulated for oral dosing at $3 \mathrm{mg} / \mathrm{ml}$ in 20\% PEG300 and 50\% Cremophor EL in water (pH 5.2), and dosed at $10 \mathrm{~mL} / \mathrm{kg}$ body weight. Dosing occurred twice per day for 4 days. Body weight was measured once per day in the morning. 
${ }^{1}$ Di, L.; Whitney-Pickett, C.; Umland, J. P.; Zhang, H.; Zhang, X.; Gebhard, D.F.; Lai, Y.; Federico, J. J.; Davidson, R.E.; Smith, R.; Reyner, E.L.; Lee, C.; Feng, B.; Rotter, C.; Varma, M.V.; Kempshall, S.; Fenner, K.; El-kattan, A.F.; Liston, T.E.; Troutman, M.D. J Pharm. Sci. 2011, 100, 4974-4985.

${ }^{2}$ Zhou L.; Yang L.; Tilton S.; Wang J. J Pharm Sci. 2007 96, 3052-3071. 